This item was submitted to Loughborough's Research Repository by the author.

Items in Figshare are protected by copyright, with all rights reserved, unless otherwise indicated.

\title{
Factors affecting the slump and strength development of geopolymer concrete
}

PLEASE CITE THE PUBLISHED VERSION

https://doi.org/10.1016/j.conbuildmat.2020.119945

PUBLISHER

Elsevier

VERSION

AM (Accepted Manuscript)

\section{PUBLISHER STATEMENT}

This paper was accepted for publication in the journal Construction and Building Materials and the definitive published version is available at https://doi.org/10.1016/j.conbuildmat.2020.119945.

LICENCE

CC BY-NC-ND 4.0

\section{REPOSITORY RECORD}

Nguyen, Thanh, Chris Goodier, and Simon Austin. 2020. "Factors Affecting the Slump and Strength Development of Geopolymer Concrete". Loughborough University. https://hdl.handle.net/2134/12961424.v1. 


\section{Factors affecting the slump and strength development of geopolymer}

\section{concrete}

Thanh T. Nguyen ${ }^{\mathrm{a}, \mathrm{b}, *}$, Chris I. Goodier ${ }^{\mathrm{a}}$, Simon A. Austin ${ }^{\mathrm{a}}$

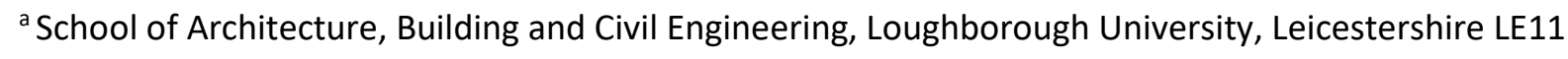
3TU, UK

${ }^{\mathrm{b}}$ Research Group of Safety, Engineering and Standards, Highways England, Bristol, BS1 6HA, UK

\section{*Corresponding author}

Email addresses: thanh.nguyen@highwaysengland.co.uk (T. Nguyen), c.i.goodier@lboro.ac.uk (C. Goodier), s.a.austin@lboro.ac.uk (S. Austin)

\section{Abstract}

Cement production is estimated to be responsible for $5-8 \%$ of global total carbon dioxide $\left(\mathrm{CO}_{2}\right)$ emissions. Geopolymer concrete (GC) is claimed to release up to $45 \%$ less $\mathrm{CO}_{2}$ for a comparable concrete, but is more difficult to manufacture. This study investigated the effect of factors other than mix design on the slump and strength development of GC produced from low-calcium fly ash (FA) and up to $50 \%$ ground granulated blastfurnace slag (GGBS) replacement; these were: curing methods and temperatures (at 10, 20 and $75^{\circ} \mathrm{C}$ ); FA fineness; superplasticiser type; water content; and GGBS/FA ratio. Methods are also presented for the volume-to-mass conversion of sodium hydroxide at a specific molarity and ambient temperature, and an effective combination of wax-based mixtures as mould agents to overcome the inherent manufacturing mould release difficulties. Steam-curing improved the compressive strength of the FA-based GC over oven drying by up to $20 \%$, as did increasing the FA fineness (although this became negligible with 50\% GGBS replacement). Both naphthalene and polycarboxylate superplasticizers improved the slump of GC (from 110 to $210 \mathrm{~mm}$ ) without significantly reducing the compressive strength $(<5 \mathrm{MPa})$. Water content of $\mathrm{GC}$ had a great 
effect on the slump, but less so on the compressive strength. Increasing the GGBS content gradually decreased the slump but rapidly increased the strength, regardless of the curing temperatures of 20 or $75{ }^{\circ} \mathrm{C}$. The GC with the minimum of $20 \%$ GGBS replacement achieved $33 \mathrm{MPa}$ after 28 days curing at $10{ }^{\circ} \mathrm{C}$. Air-dry curing provided a greater strength development of FA-based GC than water curing, though the opposite was observed for the 50/50 GGBS/FA GC. Consideration of these factors can significantly ease the manufacture of GC, enhancing its potential application in real structures, and consequently helping reduce global $\left(\mathrm{CO}_{2}\right)$ emissions.

\section{Keywords}

Geopolymer concrete; Alkali-activated materials; Fly ash; Ground granulated blastfurnace slag; Sodium hydroxide molarity; Mould release agent; Superplasticisers; Low temperature curing conditions; Slump; Compressive strength.

\section{Introduction}

Portland cement (PC), the primary binder to produce concrete, has become the most man-made material consumed worldwide with a total global production of $4.6 \mathrm{Gt} / \mathrm{year}$ [1]. In addition, cement production is estimated to be responsible for $5-8 \%$ of global total carbon dioxide $\left(\mathrm{CO}_{2}\right)$ emissions $[2,3]$. To try and address this issue, many approaches have been considered e.g. reducing $\mathrm{CO}_{2}$ emissions from PC production by burning waste raw materials, increasing efficiency of the manufacturing process, and developing $\mathrm{CO}_{2}$ capture and storage [4]; incorporating a higher percentage of mineral admixtures such as fly ash (FA) and ground granulated blastfurnace slag (GGBS) in blended PC $[5,6]$; and adopting alternative cement-like binders $[7,8]$.

Alkali-activated materials (AAMs) are a promising alternative to PC. They are synthesised from the reaction product of an amorphous aluminosilicate-rich powder (binder) activated by an alkali metal source [9], which can create concrete with up to $45 \%$ less $\mathrm{CO}_{2}$ than a typical PC-based counterpart $[10,11]$. The binder can come from natural sources such as metakaolin (MK) and pozzolan, or industrial by-products such as GGBS and FA, whilst the alkaline activators include alkali hydroxides, silicates and 
carbonates [12]. It has been shown that alkali-activated concrete can have comparable mechanical properties to PC concrete, as well as improvements in resistance to fire and aggressive chemical attack $[13,14]$.

Depending on the source of aluminosilicate, AAMs can be categorised into two key gel systems $[9,15]$. If geopolymers [16-18], the activation products of low-calcium binder sources including FA and/or MK are dominated by amorphous three-dimensional alkaline aluminosilicate hydrate (N-A-S-H) gels [19], the high-calcium sources such as alkali activated GGBS have the reaction products dominated by alkali charge-balanced aluminium-substituted calcium silicate hydrate (C-A-S-H) gels, which are similar to the C-S-H gels observed in PC $[20,21]$. In between these systems, the coexistence of N-A-S- $(\mathrm{H})$ and CA-S-H gels have been observed by alkaline activation of FA/GGBS $[22,23]$ where the dominant product is strongly influenced by the FA/GGBS ratio. This study used the term geopolymer concrete (GC) because it focused on the slump and strength development of low calcium FA-based systems with up to $50 \%$ GGBS replacement, part of a larger research programme investigating the performance of the $\mathrm{GC}$ initially cured at a range of temperatures from 10 to $75^{\circ} \mathrm{C}$, to be published elsewhere $[24,25]$. In order to develop an optimal mix design for GC, the main factors which affect the mechanical strength development must be established. Many studies on GC, however, have concentrated on identifying optimal mix proportions based on the aggregate content, alkaline activator-to-binder ratio, molarity of sodium hydroxide, sodium silicate-to-sodium hydroxide ratio, superplasticizer-to-binder ratio, and water-to-solid ratio, and in particular the influence of curing temperature and duration [2630]. Several guidelines have also been published [31-34]. However, other factors, regardless of the mix proportions, such as initial curing method by steam or oven [26], binder particle size [35-37], superplasticizer type [26,38-46], and in-air or -water curing [47] also have significant effects on the workability or strength development of GCs. These lack systematic investigation and were therefore investigated in this study.

More specifically, this study examined seven factors that influence the performance of GC (listed in the first columns of Table 2 in Section 2.2) including slump and strength development, as follows: 
1. Initial curing conditions: Oven vs Steam;

2. Finest of FA: type $\mathrm{N}$ vs type $\mathrm{S}$;

3. Types of superplasticiser: two naphthalenes (Conplast Sp430 and Daracem 215) vs two polycarboxylates (Viscocrete 10 and Glenium 51);

4. Water/solid ratios (with Alkaline/binder ratios of $0.3 \mathrm{ad} 0.4$ )

5. FA replacement with up to $50 \%$ GGBS (with GGBS/binder ratios of $0.0 ; 0.1 ; 0.2 ; 0.3 ; 0.4$; and $0.5)$, initially cured at 20 and $75^{\circ} \mathrm{C}$;

6. Initial curing at ambient temperatures of 10 (for at least 7 days) and $20^{\circ} \mathrm{C}$;

7. In-air or -water curing conditions until being tested after the initial curing at 20 or $75{ }^{\circ} \mathrm{C}$.

Practical mould release agents were also trialled and a volume-to-mass conversion method was developed to identify the mass of solid sodium hydroxide dissolved into water at a specified molarity and ambient temperature to produce an 1-kg sodium hydroxide solution. The strength development of GGBS/FA GC cured at as low as $10^{\circ} \mathrm{C}$, has never been reported, but is important for the application of GC in temperate climates such as Europe.

\section{Experimental details}

\subsection{Materials}

The binders for the GCs were low-calcium FA and GGBS. The two FAs used had fineness categories $S$ and $\mathrm{N}$, which did not respectively exceed 12 and $40 \%$ by mass retained when sieved on a $0,045 \mathrm{~mm}$ mesh sieve. These, provided by CEMEX Ltd and conforming to BS EN 450-1 [48], differed only in fineness (Figure 1) as they were produced from the same located source and process. The GGBS was supplied by Hanson plc, to BS EN 15167-1 [49]. The chemical compositions by X-ray fluorescence (XRF) spectrometry are given in Table 1, and the particle size distributions by a Mastersizer 2000 are shown in Figure 1.

The alkaline activator was blends of sodium silicate and sodium hydroxide. The sodium silicate solution, commercially available as Crystal 100 with a specific gravity of $1.50 \mathrm{~g} / \mathrm{cm}^{3}$, and containing 14 

hydroxide solution was prepared by stirring the Caustic soda pearls (solid $\mathrm{NaOH}$ ), which was slowly added into the distilled water at a specific mass ratio calculated using the method recommended in Section 2.5. Four types of superplasticizer (SP) were investigated: two naphthalene types (Conplast Sp430 and Daracem 215) and two polycarboxylate types (Viscocrete 10 and Glenium 51). BASF Glenium 51 superplasticizer was selected to provide the necessary workability.

Table 1: Chemical composition and physical properties of FA type S and type N, and GGBS.

\begin{tabular}{|c|c|c|}
\hline Oxide Composite & $\begin{array}{l}\mathrm{FA}^{*} \\
\text { (wt.\%) }\end{array}$ & $\begin{array}{l}\text { GGBS } \\
\text { (wt.\%) }\end{array}$ \\
\hline $\mathrm{SiO}_{2}$ & 54.14 & 36.50 \\
\hline $\mathrm{Al}_{2} \mathrm{O}_{3}$ & 26.65 & 11.60 \\
\hline $\mathrm{CaO}$ & 3.36 & 39.46 \\
\hline $\mathrm{Fe}_{2} \mathrm{O}_{3}$ & 6.51 & 0.43 \\
\hline $\mathrm{Na}_{2} \mathrm{O}$ & 1.07 & 0.39 \\
\hline $\mathrm{K}_{2} \mathrm{O}$ & 2.58 & 0.68 \\
\hline MgO & 1.20 & 8.14 \\
\hline $\mathrm{SO}_{3}$ & 0.41 & 0.73 \\
\hline $\mathrm{P}_{2} \mathrm{O}_{5}$ & 0.38 & - \\
\hline $\mathrm{TiO}_{2}$ & 0.60 & 0.84 \\
\hline L.o.I (wt.\%) & 3.10 & 0.03 \\
\hline Specific Gravity & $2.265(2.220)$ & 2.880 \\
\hline Specific Surface Area $\left(\mathrm{m}^{2} / \mathrm{kg}\right)$ & $2770(3320)$ & 2390 \\
\hline
\end{tabular}




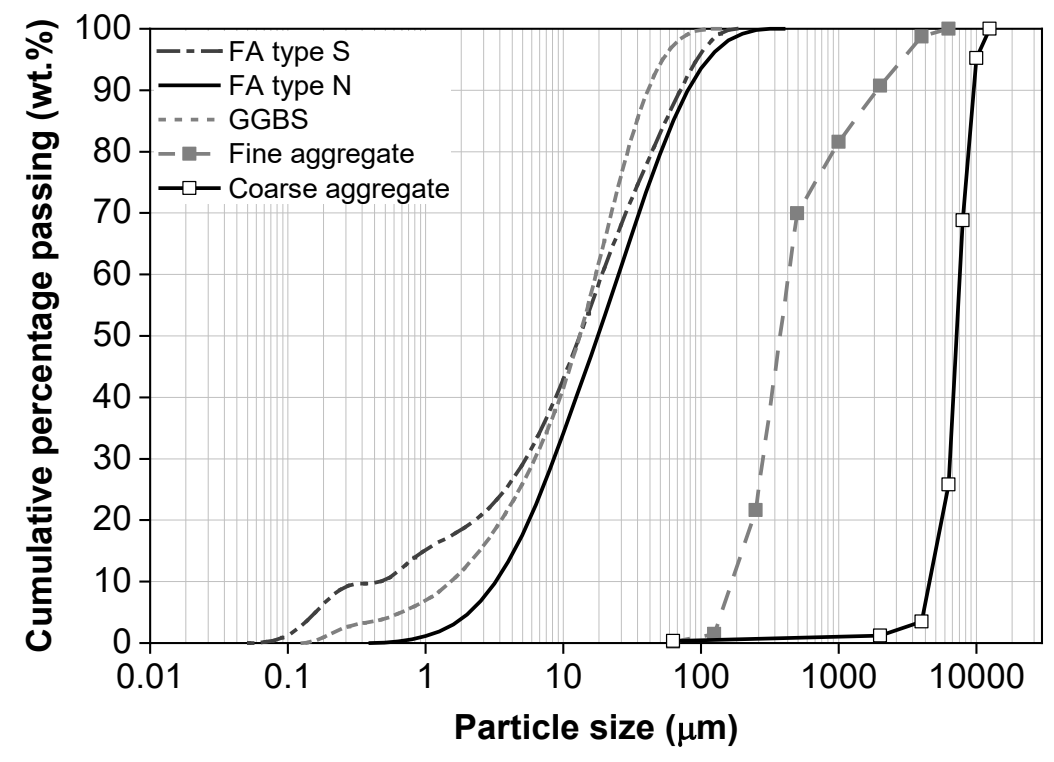

Figure 1: Particle size distribution of FA type $S$ and N, GGBS, fine and coarse aggregates.

110 The fine aggregate was Zone II sand and coarse aggregate was uncrushed river gravel with the maximum size of $10 \mathrm{~mm}$, from Portaway Minerals Ltd. They had saturated and surface-dried particle densities of 2.61 and $2.57 \mathrm{Mg} / \mathrm{m}^{3}$, respectively. The water absorption of the fine and coarse aggregates was evaluated at intervals of 15, 30, 40 and $50 \mathrm{~min}$, and $24 \mathrm{~h}$ (Figure 2). Both density and water absorption were determined according to BS EN 1097-6 [50]. The particle size distribution of the fine and coarse aggregates, measured in accordance with BS EN 933-1 [51], is also shown in Figure 1. The aggregates were dried in-house by built-in spiral elevators made by Podmores (Engineers) Ltd and left to cool naturally in a hopper before mixing of the concrete. The moisture of the aggregates, measured twice a month by the oven-dried method as described in BS EN 1097-5 [52], varied from 0 to $0.3 \%$. Tap water at $20 \pm 2{ }^{\circ} \mathrm{C}$ was used throughout the mixing and testing processes. 


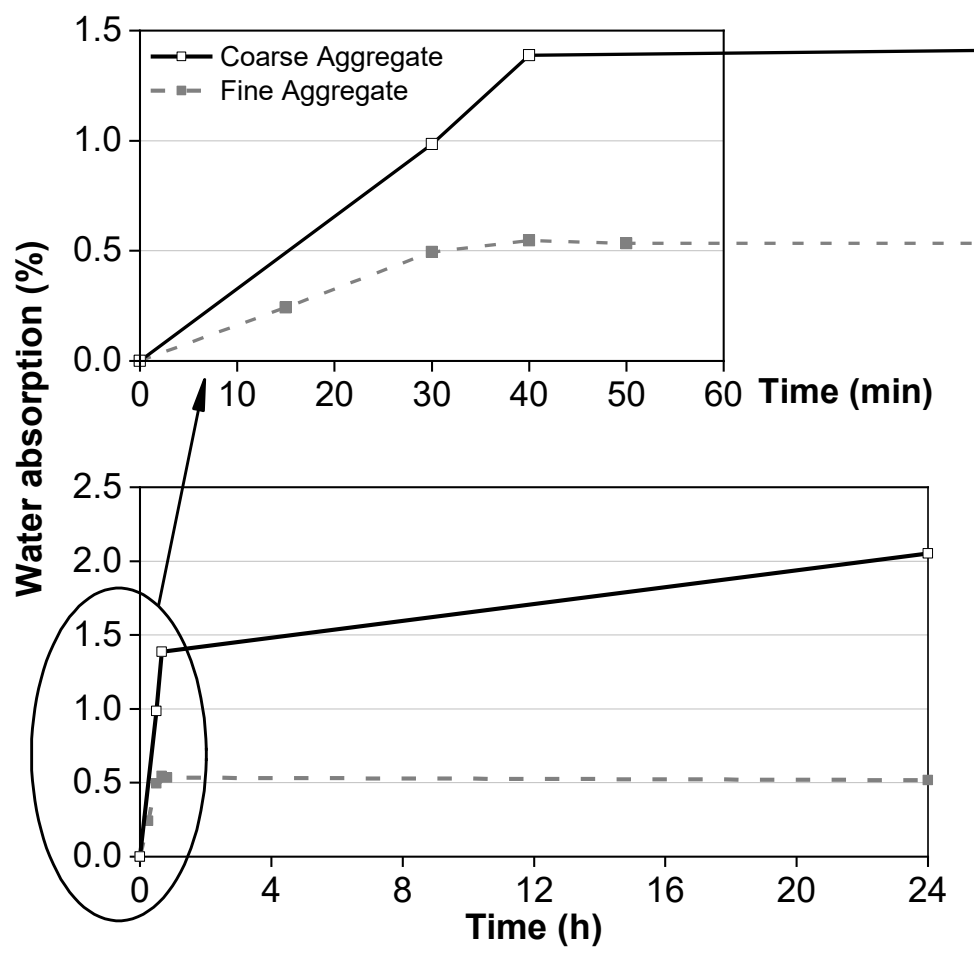

Figure 2: Water absorption of fine and coarse aggregates from oven-dried to saturated surface-dry state.

\subsection{Mix proportions}

The mix design calculations for the GCs were based on Rangan [31], in which the density of the targeted GCs is assumed to be $2400 \mathrm{~kg} / \mathrm{m}^{3}$ [26,27], and the mix proportions (ratios by mass) based on literature [26-29,53-56] were determined, including total aggregates/GC, fine aggregate/total aggregates, alkaline solution/(FA+GGBS), sodium silicate/sodium hydroxide, GGBS/(FA+GGBS), superplasticizer/(FA+GGBS). The actual amounts of raw materials for one cubic meter of $G C$ were then calculated. Three curing temperatures of 10,20 and $75{ }^{\circ} \mathrm{C}$ were selected. The mix proportion and curing conditions are presented in Table 2; the justification for the variables investigated are outlined at the end of section 1 (Introduction). According to this, each ID number from 1 to 7 listed in the rows in Table 2 represents a different factor investigated, such as the fineness of FA particles, inclusion of up to $50 \%$ GGBS, initial heat curing by oven or steam, long-term curing method by air-drying or in water, prolonged curing regime at a low temperature of $10{ }^{\circ} \mathrm{C}$, and water-to-solid ratio $(\mathrm{w} / \mathrm{s})$. 

size, when FA type $\mathrm{S}$ was then replaced by type $\mathrm{N}$. It is also worth noting that the $\mathrm{w} / \mathrm{s}$ ratio in column (j) - Table 2 was calculated according to Eq. 1 .

$$
w / s=\frac{m_{\text {water }}}{m_{\text {solid }}}=\frac{m_{\text {added_water }}+m_{\text {water_in_SS }}+m_{\text {water_in_SH }}}{m_{F A+G G B S}+m_{\text {solid_in_sS }}+m_{\text {solid_in_sH }}}
$$

Where $m_{\text {water }}$ is the total amount of water $(\mathrm{kg}) ; m_{\text {added_water }}$ is the extra water added during the casting phase of the GC excluding the amount of water absorption (Table 2) by the dried aggregates for 30 mins, $(\mathrm{kg}) ; m_{\text {water_in_ss }}$ and $m_{\text {water_in_SH }}$ are the water contents within the sodium silicate and sodium hydroxide solutions respectively $(\mathrm{kg})$. Meanwhile, $m_{\text {solid }}$ is the total solid content $(\mathrm{kg}) ; m_{F A+G G B S}$ is the mass of the binder $(\mathrm{kg})$; and $m_{\text {solid_in_ss }}$ and $m_{\text {solid_in_sH }}$ are the masses of solid substance contained in the sodium silicate and sodium hydroxide solutions, respectively $(\mathrm{kg})$. From Table 2, Mix $1 \mathrm{C}$ could be considered as the standard/baseline/control mix design $[26,27]$; the others were determined by changing the mix design parameters of Mix $1 \mathrm{C}$ in columns (c), (e), (h) and (j), or the curing conditions in columns $(t)$ and $(u)$ to meet the requirements for each of seven factors set out in column (a). For example, compared to Mix 1C, Mixes $2 A$ and $4 B$ were identical Mix $1 B$ had a reduction of the aggregates content (Agg/GC ratio - column (c)) from 0.77 to 0.70 ; Mixes $2 \mathrm{~B}$ and $2 \mathrm{C}$ had $50 \%$ of GGBS replacement with FA (GGBS/binder ratio - column (h)) and were cured at 20 and 75 ${ }^{\circ} \mathrm{C}$ (columns (t) and (u)), respectively; and so on. 


\begin{tabular}{|c|c|c|c|c|c|c|c|c|c|c|c|c|c|c|c|c|c|c|c|c|c|}
\hline \multirow[t]{3}{*}{ Factors } & \multirow[t]{3}{*}{ ID } & \multirow{3}{*}{$\begin{array}{l}\text { Agg/ } \\
\text { GC } \\
{[26,28]}\end{array}$} & \multirow{3}{*}{$\begin{array}{l}\text { Fine } \\
\text { agg/ } \\
\text { Agg } \\
{[27,28]}\end{array}$} & \multirow{3}{*}{$\begin{array}{l}\text { Alk/ } \\
\text { Binder } \\
\\
{[26,27]}\end{array}$} & \multirow{3}{*}{$\begin{array}{l}\text { SS/SH } \\
\\
{[26,28]}\end{array}$} & \multirow{3}{*}{$\begin{array}{l}\mathrm{NaOH} \\
\text { solution } \\
\text { (M) } \\
{[53-55]}\end{array}$} & \multirow{3}{*}{$\begin{array}{l}\text { GGBS/ } \\
\text { Binder }\end{array}$} & \multirow{3}{*}{$\begin{array}{l}\text { SP/ } \\
\text { Binder } \\
(\%) \\
{[26]}\end{array}$} & \multirow[t]{3}{*}{$w / s$} & \multicolumn{7}{|c|}{ Quantity (kg) } & \multirow{3}{*}{$\begin{array}{l}\text { Water for } \\
\text { - aggregates } \\
\text { absorption } \\
\text { (kg) }\end{array}$} & \multirow{3}{*}{$\begin{array}{l}\text { Added } \\
\text { water } \\
\text { (kg) }\end{array}$} & \multicolumn{3}{|c|}{ Initial Curing $[27,29,56]$} \\
\hline & & & & & & & & & & \multirow{2}{*}{$\begin{array}{l}\text { Coarse } \\
\text { agg. }\end{array}$} & \multirow{2}{*}{$\begin{array}{l}\text { Fine } \\
\text { agg. }\end{array}$} & \multicolumn{2}{|l|}{ Binder } & \multirow{2}{*}{$\begin{array}{l}\mathrm{NaOH} \\
\text { solution }\end{array}$} & \multirow{2}{*}{\multicolumn{2}{|c|}{$\begin{array}{l}\text { Sodium SP } \\
\text { silicate }\end{array}$}} & & & \multirow{2}{*}{$\begin{array}{l}\text { Time } \\
\text { (h) }\end{array}$} & \multirow{2}{*}{$\begin{array}{l}\text { Temp } \\
\left({ }^{\circ} \mathrm{C}\right)\end{array}$} & \multirow[t]{2}{*}{ Method } \\
\hline & & & & & & & & & & & & FA & GGBS & & & & & & & & \\
\hline (a) & (b) & (c) & (d) & (e) & (f) & (g) & (h) & (i) & (j) & (k) & (I) & (m) & (n) & (o) & (p) & (q) & $(r)$ & (s) & $(t)$ & (u) & (v) \\
\hline \multirow{3}{*}{$\begin{array}{l}\text { Initial curing conditions: } \\
\text { Oven vs Steam }\end{array}$} & $1 \mathrm{~A}$ & 0.70 & 0.35 & 0.30 & 2.5 & 12 & - & 1.5 & 0.20 & 1092.0 & 588.0 & 553.8 & - & 47.5 & 118.7 & 8.3 & 13.6 & 24.5 & 24 & 75 & Oven/Steam \\
\hline & $1 \mathrm{~B}$ & 0.70 & 0.35 & 0.30 & 2.5 & 12 & - & 1.5 & 0.22 & 1092.0 & 588.0 & 553.8 & - & 47.5 & 118.7 & 8.3 & 13.6 & 36.0 & 24 & 75 & Oven/Steam \\
\hline & $1 \mathrm{C}$ & 0.77 & 0.35 & 0.30 & 2.5 & 12 & - & 1.5 & 0.22 & 1201.2 & 646.8 & 424.6 & - & 36.4 & 91.0 & 6.4 & 15.0 & 27.3 & 24 & 75 & Oven/Steam \\
\hline Finest of FA: & $2 \mathrm{~A}$ & 0.77 & 0.35 & 0.30 & 2.5 & 12 & - & 1.5 & 0.22 & 1201.2 & 646.8 & 424.6 & - & 36.4 & 91.0 & 6.4 & 15.0 & 27.3 & 24 & 75 & Steam \\
\hline type $\mathrm{N}$ vs type $\mathrm{S}$ & $2 B$ & 0.77 & 0.35 & 0.30 & 2.5 & 12 & 0.5 & 1.5 & 0.24 & 1201.2 & 646.8 & 212.3 & 212.3 & 36.4 & 91.0 & 6.4 & 15.0 & 38.0 & 24 & 20 & Amb. \\
\hline & $2 \mathrm{C}$ & 0.77 & 0.35 & 0.30 & 2.5 & 12 & 0.5 & 1.5 & 0.24 & 1201.2 & 646.8 & 212.3 & 212.3 & 36.4 & 91.0 & 6.4 & 15.0 & 38.0 & 24 & 75 & Steam \\
\hline Two types of superplasticiser & 3 & 0.77 & 0.35 & 0.30 & 2.5 & 12 & - & 1.5 & 0.24 & 1201.2 & 646.8 & 424.6 & - & 36.4 & 91.0 & 6.4 & 15.0 & 38.0 & 24 & 75 & Steam \\
\hline $\mathrm{W} / \mathrm{s}$ ratios: & $4 \mathrm{~A}$ & 0.77 & 0.35 & 0.30 & 2.5 & 12 & - & 1.5 & 0.20 & 1201.2 & 646.8 & 424.6 & - & 36.4 & 91.0 & 6.4 & 15.0 & 19.0 & 24 & 75 & Steam \\
\hline with alkali & $4 \mathrm{~B}$ & 0.77 & 0.35 & 0.30 & 2.5 & 12 & - & 1.5 & 0.22 & 1201.2 & 646.8 & 424.6 & - & 36.4 & 91.0 & 6.4 & 15.0 & 27.3 & 24 & 75 & Steam \\
\hline o & $4 C$ & 0.77 & 0.35 & 0.30 & 2.5 & 12 & - & 1.5 & 0.24 & 1201.2 & 646.8 & 424.6 & - & 36.4 & 91.0 & 6.4 & 15.0 & 38.0 & 24 & 75 & Steam \\
\hline & $4 \mathrm{D}$ & 0.77 & 0.35 & 0.30 & 2.5 & 12 & - & 1.5 & 0.30 & 1201.2 & 646.8 & 424.6 & - & 36.4 & 91.0 & 6.4 & 15.0 & 66.5 & 24 & 75 & Steam \\
\hline & $\overline{4 E}$ & 0.77 & 0.35 & 0.40 & 2.5 & 12 & - & 1.5 & 0.22 & 1201.2 & 646.8 & 394.3 & - & 45.1 & 112.7 & 5.9 & 15.0 & 5.4 & 24 & 75 & Steam \\
\hline & $4 \mathrm{~F}$ & 0.77 & 0.35 & 0.40 & 2.5 & 12 & - & 1.5 & 0.24 & 1201.2 & 646.8 & 394.3 & - & 45.1 & 112.7 & 5.9 & 15.0 & 15.4 & 24 & 75 & Steam \\
\hline & $4 \mathrm{G}$ & 0.77 & 0.35 & 0.40 & 2.5 & 12 & - & 1.5 & 0.30 & 1201.2 & 646.8 & 394.3 & - & 45.1 & 112.7 & 5.9 & 15.0 & 42.8 & 24 & 75 & Steam \\
\hline FA replacem & $5 \mathrm{~A}$ & 0.77 & 0.35 & 0.30 & 2.5 & 12 & 0.0 & 1.5 & 0.24 & 1201.2 & 646.8 & 424.6 & - & 36.4 & 91.0 & 6.4 & 15.0 & 38.0 & 24 & $20 / 75$ & Amb./Steam \\
\hline $50 \%$ GGBS, initially cured at & $5 B$ & 0.77 & 0.35 & 0.30 & 2.5 & 12 & 0.1 & 1.5 & 0.24 & 1201.2 & 646.8 & 382.2 & 42.5 & 36.4 & 91.0 & 6.4 & 15.0 & 38.0 & 24 & $20 / 75$ & Amb./Steam \\
\hline 20 and $75^{\circ} \mathrm{C}$ & $5 C$ & 0.77 & 0.35 & 0.30 & 2.5 & 12 & 0.2 & 1.5 & 0.24 & 1201.2 & 646.8 & 339.7 & 84.9 & 36.4 & 91.0 & 6.4 & 15.0 & 38.0 & 24 & $20 / 75$ & Amb./Steam \\
\hline & $5 D$ & 0.77 & 0.35 & 0.30 & 2.5 & 12 & 0.3 & 1.5 & 0.24 & 1201.2 & 646.8 & 297.2 & 127.4 & 36.4 & 91.0 & 6.4 & 15.0 & 38.0 & 24 & $20 / 75$ & Amb./Steam \\
\hline & $5 \mathrm{E}$ & 0.77 & 0.35 & 0.30 & 2.5 & 12 & 0.4 & 1.5 & 0.24 & 1201.2 & 646.8 & 254.8 & 169.8 & 36.4 & 91.0 & 6.4 & 15.0 & 38.0 & 24 & $20 / 75$ & Amb./Steam \\
\hline & $5 F$ & 0.77 & 0.35 & 0.30 & 2.5 & 12 & 0.5 & 1.5 & 0.24 & 1201.2 & 646.8 & 212.3 & 212.3 & 36.4 & 91.0 & 6.4 & 15.0 & 38.0 & 24 & $20 / 75$ & Amb./Steam \\
\hline Initial curing at ambient & $6 \mathrm{~A}$ & 0.77 & 0.35 & 0.40 & 2.5 & 12 & 0.2 & 1.5 & 0.24 & 1201.2 & 646.8 & 315.4 & 78.9 & 45.1 & 112.7 & 5.9 & 15.0 & 15.4 & 168 & 10 & Amb. \\
\hline & $6 B$ & 0.77 & 0.35 & 0.40 & 2.5 & 12 & 0.2 & 1.5 & 0.24 & 1201.2 & 646.8 & 315.4 & 78.9 & 45.1 & 112.7 & 5.9 & 15.0 & 15.4 & 24 & 20 & Amb. \\
\hline le & $6 C$ & 0.77 & 0.35 & 0.30 & 2.5 & 12 & 0.3 & 1.5 & 0.24 & 1201.2 & 646.8 & 297.2 & 127.4 & 36.4 & 91.0 & 6.4 & 15.0 & 38.0 & 24 & 20 & Amb. \\
\hline In-air or -water curing & $7 \mathrm{~A}$ & 0.77 & 0.35 & 0.30 & 2.5 & 12 & - & 1.5 & 0.25 & 1201.2 & 646.8 & 424.6 & - & 36.4 & 91.0 & 6.4 & 15.0 & 42.5 & 24 & 75 & Steam \\
\hline & $7 \mathrm{~B}$ & 0.77 & 0.35 & 0.30 & 2.5 & 12 & 0.5 & 1.5 & 0.30 & 1201.2 & 646.8 & 212.3 & 212.3 & 36.4 & 91.0 & 6.4 & 15.0 & 66.5 & 24 & 20 & Amb. \\
\hline & $7 C$ & 0.77 & 0.35 & 0.30 & 2.5 & 12 & 0.5 & 1.5 & 0.30 & 1201.2 & 646.8 & 212.3 & 212.3 & 36.4 & 91.0 & 6.4 & 15.0 & 66.5 & 24 & 75 & Steam \\
\hline
\end{tabular}

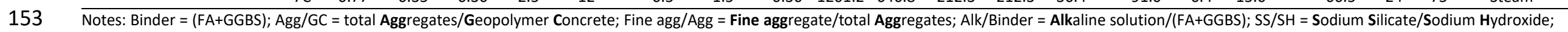




\subsection{Specimen preparation}

156

157

158

159

160

161

162

163

164

\subsubsection{Mould coating method}

Mould release agents are normally applied to prevent concrete from adhering to the steel mould due to a thin layer of material with high lubrication properties (e.g. oil or wax) being applied before casting [57]. As a result, it makes demoulding easier and provides a smooth finished surface for the hardened concrete, as well as increasing the corrosion resistance of the steel mould. However, typical release agents commercially available for PC concretes are often inappropriate for GC. During some trials to produce the FA-based GC cubes, it was observed that despite commonly-used commercial release agents, for example Kingfisher and Sika release agents, being applied before the casting process, the GC adhered very strongly to the inner surfaces of the steel mould, so that the resultant struck cubes had either very rough finished surfaces (with aggregates often partially or completely exposed), or they were badly broken apart during demoulding. In addition, rust on the external surface of the steel mould was also developed due to steam-curing.

Unfortunately, no published studies have reported this issue in detail or with any substantial data, except for, for example, some general recommendations to apply "generally thick coatings of a viscous wax-based mould-release agent" [58] or a combination of various oils such as aliphatic compounds and waxes for the aluminium mould [59]. Therefore, an initial trial investigation was essential to develop an appropriate and effective release agent and coating process to produce samples efficiently as per the standardised requirements (BS EN 12390-1:2012 [60]) for mechanical and durability tests, together with a practicable demoulding process similar to that for PC concrete. Ten mould release agents were investigated (Table 3), including three designed for PC concrete with more specific properties closely related to the curing conditions of FA-based GC, as well as seven waxbased agents. Mix $1 \mathrm{C}$ was selected to investigate the effect of the release agents in Table 3 on 100 $\mathrm{mm}^{3}$ moulds and specimens steam-cured at temperatures from 40 to $100{ }^{\circ} \mathrm{C}$ and for $24 \mathrm{~h}$. 


\begin{tabular}{|c|c|c|c|}
\hline \multicolumn{2}{|c|}{ Mould release agents from industry } & \multicolumn{2}{|c|}{ Wax-based release agents } \\
\hline Name & Properties & Name & Properties \\
\hline $\begin{array}{l}\text { Kingfisher } \\
\text { mould release } \\
\text { oil [61] }\end{array}$ & $\begin{array}{l}\text { - A hydrocarbon and fatty acid blend } \\
\text { - Used with metal or timber moulds } \\
\text { - Resultant concrete has a smooth, } \\
\text { hard, uniform finish with reduced } \\
\text { incidence of blow holes }\end{array}$ & $\begin{array}{l}\text { NikWax Leather } \\
\text { Cleaner; } \\
\text { Cherry Blossom } \\
\text { Wax \& Shine; } \\
\text { Neatsfoot Oil; } \\
\text { Woly Shoe Wax; } \\
\text { or Vaseline }\end{array}$ & $\begin{array}{l}\text { - Blend of waxes and oils } \\
\text { - Primarily used in the treatments of } \\
\text { leather to replace the natural oil }\end{array}$ \\
\hline $\begin{array}{l}\text { Sika Release } \\
{[62]}\end{array}$ & $\begin{array}{l}\text { - A concrete release agent for } \\
\text { precast or in-situ concrete } \\
\text { - Used on steel, shuttering plywood, } \\
\text { timber or plastic faced formwork } \\
\text { - Improves surface finish and } \\
\text { increases form work reuse }\end{array}$ & Z30 Fluid [63] & $\begin{array}{l}\text { - Good dewatering properties and } \\
\text { penetration } \\
\text { - Dry thin, flexible film doesn't attract } \\
\text { dirt or dust } \\
\text { - Not contain silicones or chlorinated } \\
\text { solvents } \\
\text { - Temperature: }-20^{\circ} \mathrm{C} \text { to }+110^{\circ} \mathrm{C}\end{array}$ \\
\hline $\begin{array}{l}\text { Sika Separol W } \\
{[64]}\end{array}$ & $\begin{array}{l}\text { - Smooth non-absorbent formwork } \\
\text { - Absorbent formwork } \\
\text { - Heated formwork (up to }+70^{\circ} \mathrm{C} \text { ) } \\
\text { - Textured formwork }\end{array}$ & Waxoyl [65] & $\begin{array}{l}\text { - Kills old rust and prevents new rust } \\
\text { - Forms a flexible weatherproof skin } \\
\text { - Apply to anywhere that water is } \\
\text { likely to collect }\end{array}$ \\
\hline
\end{tabular}

As a result, the following coating method was developed based on the outcomes of the investigation minimum interval of $12 \mathrm{~h}$ for a natural drying of the first layer of Z30. Another minimum of $12 \mathrm{~h}$ was necessary for the second layer of Waxoyl to be naturally dried before casting the GC. The externally exposed part of the mould was then coated with Waxoyl before all steam curing at $30^{\circ} \mathrm{C}$ or above.

\subsubsection{Mixing procedures and curing conditions}

The sodium hydroxide solution was produced in a fume cupboard as described in Section 2.1, which was then stored in an airtight container for at least 24 hours to allow it to cool down to room temperature $\left(20 \pm 2{ }^{\circ} \mathrm{C}\right)$ before slowly pouring into and mixing by hand with the sodium silicate to produce an activator solution. The alkaline activator was prepared at a designated mass ratio ( $\mathrm{SH} / \mathrm{SS}$ ratio in Table 2) at least 2 hours before mixing the concrete. Extra water and superplasticizer were then added to the blended activator solution. The extra water comprised the added water (column (s) 
determined from the 30-min water absorption of the aggregates to achieve the saturated surface-dry state (SSD).

All dry materials, including coarse and fine aggregates and binder (the FA, with or without GGBS), were thoroughly pre-mixed in a 35-litre laboratory pan rotary mixer for about three minutes until all the constituents were evenly distributed. The blended alkaline activator solution was then poured slowly into the running mixer for about a minute. The wet mixing was then continued for a further three more minutes. After conducting the slump test within the first 5 mins, the fresh GC was placed immediately into the prepared $100 \mathrm{~mm}^{3}$ moulds in at least three equal layers to reduce air voids entrapped within the GC more effectively. For each layer, the vibration table was run for a sufficient time to create a fully compacted concrete, typically between 15 seconds to several minutes at a frequency level of about 6/10. Care was taken to ensure that segregation and bleeding did not occur (i.e. coarse aggregate was still visible at the top surface). The moulds were then sealed with thin polythene sheets and immediately placed into an environmentally controlled room at $20 \pm 2{ }^{\circ} \mathrm{C}$ and $65 \pm 5 \% \mathrm{RH}$ for a maximum of one hour before initial curing. Depending on the designated initial curing regime, the specimens were heat-cured in an oven or a steam-curing tank for $24 \mathrm{~h}$, or in an environmentally controlled chamber at $10{ }^{\circ} \mathrm{C}$ and $65 \pm 5 \% \mathrm{RH}$ for a minimum of 7 days. After the initial curing period, the specimens were then stripped from the moulds, marked with ID numbers and placed in air in the environmentally controlled room at $20 \pm 2{ }^{\circ} \mathrm{C}$ and $65 \pm 5 \% \mathrm{RH}$ until being tested.

\subsection{Fresh and hardened properties}

A slump test complying with BS EN 12350-2 [66] was conducted once for every mix, immediately after mixing. Demoulded specimens were "as-received" samples [67] to record the masses and dimensions, which were used to calculate the volume and concrete hardened densities in accordance with BS EN 12390-7 [67]. All hardened properties were tested on $100 \mathrm{~mm}^{3}$ cubes. The compressive strength was measured conforming to BS EN 12390-3 [68], with a loading rate of $0.6 \mathrm{MPa}$ /s. The water absorption was evaluated as a percentage of the difference in mass between oven dried and SSD cube specimens 

concrete hardened property tests, a mean of three measurements was reported.

\subsection{Volume-to-mass conversion of sodium hydroxide solution at a specific molarity and temperature} In theory, to produce a litre of a sodium hydroxide solution having an $\mathrm{N}$ molarity, $(\mathrm{M} \times \mathrm{N})$ grams of solid sodium hydroxide are dissolved into water (to generate exactly one litre of the solution), where $M$ is the molar mass of solid sodium hydroxide. But it is very difficult to precisely measure the volume of a solution, in particular a large one. In practice, to avoid this issue, a percentage of $\mathrm{Na}_{2} \mathrm{O}$ dosage was used instead to manufacture GC [70-73], leading to a complicated calculation of the alkaline modulus $\left(\mathrm{Na}_{2} \mathrm{O} / \mathrm{SiO}_{2}\right.$ ratio). A simpler method can be achieved by converting volume-to-mass of the sodium hydroxide solution as a mass measurement, which is always easier and highly accurate compared to that of a volume.

Many studies $[29,54,55]$ have used sodium hydroxide molarities without any statement of how to precisely produce such solutions, whereas others $[28,32,74]$ applied the converted values from volume-to-mass of sodium hydroxide as suggested by [26], but without verifying how they were calculated or measured.

In order to make the preparation process of sodium hydroxide solution more practical and accurate, a method was developed to describe the conversion calculation from volume-to-mass. To begin with, the concentration by mass of sodium hydroxide in a sodium hydroxide solution at $T\left({ }^{\circ} \mathrm{C}\right)$ temperature can be defined and calculated according to Equation Eq. 2.

$$
C_{T}(\%)=\frac{m_{\mathrm{NaOH}_{\text {solid }}}}{m_{\mathrm{NaOH}_{\text {solution }}}} \times 100
$$
where, $C_{T}$ is the concentration by mass of sodium hydroxide in the solution at $T\left({ }^{\circ} \mathrm{C}\right)$ temperature

240 (\%mass/mass); $m_{\mathrm{NaOH}_{-} \text {solid }}$ is the mass of the solid sodium hydroxide dissolved $(\mathrm{g})$; and $m_{\mathrm{NaOH} \text { solution }}$ is the mass of the sodium hydroxide solution (g). 
242 To produce $V_{0}$ (litres) of a sodium hydroxide solution with an $N$ molarity, a mass of solid sodium

243 hydroxide equal to $\left(M \times N \times V_{0}\right)$ grams is needed, where $N$ is the molarity of the sodium hydroxide

244 solution ( $\mathrm{mol} / \mathrm{l}) ; M=39.99711$ is the molar mass of solid sodium hydroxide $(\mathrm{g} / \mathrm{mol})$. Whereas the mass

245 of this sodium hydroxide solution equal to $\left(D_{T} \times V_{0}\right)$ grams can be calculated using the solution density

246 presented in Table 4, where $D_{T}$ is the density of the sodium hydroxide solution $(\mathrm{kg} / \mathrm{l}=1000 \mathrm{~g} / \mathrm{l})$ at $T$

$247\left({ }^{\circ} \mathrm{C}\right)$ temperature. The Equation Eq. 3 presenting a series of hyperbola curves is then derived by 248 substituting the two above parameters into Equation Eq. 2 with a specific molarity $-N$ and at $T\left({ }^{\circ} \mathrm{C}\right)$

249 temperature.

250

$$
D_{T}=3.99971 \times N \times C_{T}^{-1}
$$

251 Meanwhile, the relationship between density $\left(D_{T}\right)$ and concentration $\left(C_{T}\right)$ can be practically evaluated

252 at a range of $T$ from 0 to $100{ }^{\circ} \mathrm{C}$ from [75], which were selected and presented in Table 4 at more ambient temperatures of up to $40^{\circ} \mathrm{C}$, at which the manufacturing of $\mathrm{GC}$ is normally occurred. At each temperature, the density and the concentration by mass seem to have a linear relationship with a high coefficient of determination $\left(R^{2}>0.999\right)$, which are represented in Eq. 4 .

Table 4: Density of sodium hydroxide solution at 1 ATM [75].

\begin{tabular}{llllllll}
\hline Concentration- $(\mathrm{C})$ & $0^{\circ} \mathrm{C}$ & $10^{\circ} \mathrm{C}$ & $15^{\circ} \mathrm{C}$ & $18^{\circ} \mathrm{C}$ & $20^{\circ} \mathrm{C}$ & $30^{\circ} \mathrm{C}$ & $40^{\circ} \mathrm{C}$ \\
\cline { 2 - 7 } (wt.\%) & \multicolumn{2}{l}{ Density- $(D)(\mathrm{kg} / \mathrm{l})$} & & & & & \\
\hline 1 & 1.0124 & 1.0115 & 1.0107 & 1.0100 & 1.0095 & 1.0069 & 1.0033 \\
2 & 1.0244 & 1.0230 & 1.0220 & 1.0213 & 1.0207 & 1.0177 & 1.0139 \\
4 & 1.0482 & 1.0459 & 1.0444 & 1.0435 & 1.0428 & 1.0393 & 1.0352 \\
6 & 1.0713 & 1.0683 & 1.0667 & 1.0656 & 1.0648 & 1.0609 & 1.0564 \\
8 & 1.0943 & 1.0908 & 1.0889 & 1.0877 & 1.0869 & 1.0826 & 1.0780 \\
10 & 1.1171 & 1.1132 & 1.1111 & 1.1098 & 1.1089 & 1.1043 & 1.0995 \\
14 & 1.1624 & 1.1578 & 1.1555 & 1.1540 & 1.1530 & 1.1480 & 1.1428 \\
18 & 1.2073 & 1.2023 & 1.1997 & 1.1982 & 1.1972 & 1.1918 & 1.1963 \\
22 & 1.2519 & 1.2465 & 1.2439 & 1.2422 & 1.2411 & 1.2454 & 1.2296 \\
26 & 1.2963 & 1.2906 & 1.2877 & 1.2860 & 1.2848 & 1.2789 & 1.2728 \\
30 & 1.3400 & 1.3340 & 1.3309 & 1.3290 & 1.3279 & 1.3217 & 1.3154 \\
34 & 1.3823 & 1.3760 & 1.3728 & 1.3708 & 1.3696 & 1.3632 & 1.3566 \\
38 & 1.4234 & 1.4168 & 1.4135 & 1.4115 & 1.4101 & 1.4035 & 1.3967 \\
42 & 1.4632 & 1.4561 & 1.4529 & 1.4508 & 1.4494 & 1.4425 & 1.4356 \\
46 & 1.5018 & 1.4947 & 1.4911 & 1.4890 & 1.4873 & 1.4805 & 1.4734 \\
50 & 1.5400 & 1.5326 & 1.5290 & 1.5268 & 1.5253 & 1.5181 & 1.5109 \\
\hline
\end{tabular}




$$
D_{T}=a_{T} \times C_{T}+b_{T}
$$

259

260

261

262

263

264

265

266

267 as shown in [75]. regression (Table 5).

where, the slope-intercept, $a_{T}$, and the constant, $b_{T}$, are dependent on the ambient temperature as shown in Table 4. It is $z$ when the concentration is zero, meaning that the solution is pure water: $b_{T}$ is ideally equal to the water density. These parameters are determined at each temperature using linear

Table 5: Parameters of Eq. 4 depending on the temperatures

\begin{tabular}{llllllll}
\hline Temperature $\left({ }^{\circ} \mathrm{C}\right)$ & 0 & 10 & 15 & 18 & 20 & 30 & 40 \\
\hline$a_{T}$ & 0.0109 & 0.0107 & 0.0107 & 0.0107 & 0.0106 & 0.0106 & 0.0105 \\
$b_{T}$ & 1.0083 & 1.0060 & 1.0045 & 1.0036 & 1.0030 & 0.9999 & 0.9960 \\
CoD, $\mathrm{R}^{2}$ & 0.9992 & 0.9993 & 0.9994 & 0.9994 & 0.9994 & 0.9993 & 0.9993 \\
\hline
\end{tabular}

By respectively substituting values of the designed molarity and the environmentally controlled temperature into Equations Eq. 3 and Eq. 4, the density and concentration would then be calculated. The results are shown in Table 6, based on which the converted mass of solid sodium hydroxide was determined for each unit mass of the solution and each unit mass of water at a specific temperature and designed molarity (Table 7). The range of sodium hydroxide molarity presented in this study (Table 6) was collected from $4 \mathrm{M}$ to $18 \mathrm{M}$ because the majority of studies used sodium hydroxide solution with a molarity of 6 to $16[26,28,32,54,55]$, whist some tried $4 \mathrm{M}[29,76]$ or $18 \mathrm{M}[77]$. Beyond this range, the impact of the sodium hydroxide solution would either be extremely low on the activation process (less than 4M) or become very corrosively aggressive for the users. However, the method proposed is straight forward and can be applied to identify the desired molarity with a concentration below $50 \%$ 


\begin{tabular}{llllllllll}
\hline Temperature $\left({ }^{\circ} \mathrm{C}\right)$ & Parameter & \multicolumn{2}{l}{ Molarity } & & & & & & \\
\cline { 2 - 10 } & & $4 \mathrm{M}$ & $6 \mathrm{M}$ & $8 \mathrm{M}$ & $10 \mathrm{M}$ & $12 \mathrm{M}$ & $14 \mathrm{M}$ & $16 \mathrm{M}$ & $18 \mathrm{M}$ \\
\hline 0 & $(1)$ & 13.806 & 19.634 & 24.986 & 29.963 & 34.634 & 39.050 & 43.249 & 47.259 \\
& $(2)$ & 1.159 & 1.222 & 1.281 & 1.335 & 1.386 & 1.434 & 1.480 & 1.523 \\
10 & $(1)$ & 13.860 & 19.719 & 25.104 & 30.113 & 34.817 & 39.264 & 43.493 & 47.534 \\
& $(2)$ & 1.154 & 1.217 & 1.275 & 1.328 & 1.379 & 1.426 & 1.471 & 1.515 \\
15 & $(1)$ & 13.876 & 19.740 & 25.128 & 30.141 & 34.847 & 39.296 & 43.527 & 47.569 \\
& $(2)$ & 1.153 & 1.216 & 1.273 & 1.327 & 1.377 & 1.425 & 1.470 & 1.513 \\
18 & $(1)$ & 13.886 & 19.752 & 25.143 & 30.157 & 34.865 & 39.315 & 43.547 & 47.590 \\
& $(2)$ & 1.152 & 1.215 & 1.273 & 1.326 & 1.377 & 1.424 & 1.470 & 1.513 \\
20 & $(1)$ & 13.907 & 19.788 & 25.194 & 30.224 & 34.946 & 39.412 & 43.659 & 47.717 \\
& $(2)$ & 1.150 & 1.213 & 1.270 & 1.323 & 1.373 & 1.421 & 1.466 & 1.509 \\
30 & $(1)$ & 13.940 & 19.831 & 25.245 & 30.281 & 35.009 & 39.479 & 43.730 & 47.790 \\
& $(2)$ & 1.148 & 1.210 & 1.267 & 1.321 & 1.371 & 1.418 & 1.463 & 1.506 \\
40 & $(1)$ & 13.998 & 19.914 & 25.351 & 30.409 & 35.158 & 39.649 & 43.918 & 47.997 \\
& $(2)$ & 1.143 & 1.205 & 1.262 & 1.315 & 1.365 & 1.412 & 1.457 & 1.500 \\
\hline Notes: (1): Concentration (\%): (2): Density (kg//l) & & & & & & &
\end{tabular}

279

Notes: (1): Concentration (\%); (2): Density (kg/l)

Table 7: Converted mass of solid sodium hydroxide

\begin{tabular}{|c|c|c|c|c|c|c|c|c|c|}
\hline \multirow[t]{2}{*}{ Temperature $\left({ }^{\circ} \mathrm{C}\right)$} & \multirow[t]{2}{*}{ Type } & \multicolumn{8}{|c|}{ Molarity } \\
\hline & & $4 \mathrm{M}$ & $6 \mathrm{M}$ & $8 \mathrm{M}$ & $10 \mathrm{M}$ & $12 \mathrm{M}$ & $14 \mathrm{M}$ & $16 \mathrm{M}$ & $18 \mathrm{M}$ \\
\hline \multirow[t]{2}{*}{0} & (A) & 138 & 196 & 250 & 300 & 346 & 391 & 432 & 473 \\
\hline & (B) & 160 & 244 & 333 & 428 & 530 & 641 & 762 & 896 \\
\hline \multirow[t]{2}{*}{10} & (A) & 139 & 197 & 251 & 301 & 348 & 393 & 435 & 475 \\
\hline & (B) & 161 & 246 & 335 & 431 & 534 & 646 & 770 & 906 \\
\hline \multirow[t]{2}{*}{15} & (A) & 139 & 197 & 251 & 301 & 348 & 393 & 435 & 476 \\
\hline & (B) & 161 & 246 & 336 & 431 & 535 & 647 & 771 & 907 \\
\hline \multirow[t]{2}{*}{18} & (A) & 139 & 198 & 251 & 302 & 349 & 393 & 435 & 476 \\
\hline & (B) & 161 & 246 & 336 & 432 & 535 & 648 & 771 & 908 \\
\hline \multirow[t]{2}{*}{20} & (A) & 139 & 198 & 252 & 302 & 349 & 394 & 437 & 477 \\
\hline & (B) & 162 & 247 & 337 & 433 & 537 & 651 & 775 & 913 \\
\hline \multirow[t]{2}{*}{30} & (A) & 139 & 198 & 252 & 303 & 350 & 395 & 437 & 478 \\
\hline & (B) & 162 & 247 & 338 & 434 & 539 & 652 & 777 & 915 \\
\hline \multirow[t]{2}{*}{40} & (A) & 140 & 199 & 254 & 304 & 352 & 396 & 439 & 480 \\
\hline & (B) & 163 & 249 & 340 & 437 & 542 & 657 & 783 & 923 \\
\hline
\end{tabular}

281

Notes: Mass of solid sodium hydroxide in gram for (A) - $1 \mathrm{~kg}$ of sodium hydroxide solution; and (B) - $1 \mathrm{~kg}$ of water

282 Compared to the measurement from [26], there are about 10 grams or $4 \%$ difference, as shown in

283 Table 8. In addition, this conversion will help specifiers avoid any complicated chemical calculations of

284 sodium oxide mass ratio $M^{+}=\frac{\mathrm{Na}_{2} \mathrm{O}}{\text { binder }}$ and alkali modulus $A M=\frac{\mathrm{Na}_{2} \mathrm{O}}{\mathrm{SiO}_{2}}$ as suggested by 
Table 8: Comparison of the measurement of solid sodium hydroxide (in grams) for each kilogramme of solution between this study and [26]

\begin{tabular}{lllllll}
\hline Comparison & Temperature $\left({ }^{\circ} \mathrm{C}\right)$ & \multicolumn{5}{l}{ Molarity } \\
\cline { 3 - 7 } & & $8 \mathrm{M}$ & $10 \mathrm{M}$ & $12 \mathrm{M}$ & $14 \mathrm{M}$ & $16 \mathrm{M}$ \\
\hline Current study & 20 & 251.9 & 302.2 & 349.5 & 394.1 & 436.6 \\
& 30 & 252.4 & 302.8 & 350.1 & 394.8 & 437.3 \\
{$[26]$} & - & 262.3 & 313.7 & 360.9 & 404.3 & 444.4 \\
\hline
\end{tabular}

A 1-kg solution of sodium hydroxide for the conversion is recommended because there is a significant amount of heat emitted during the dissolution process leading to a large amount of water evaporated. The water can then be added up to produce a 1-kg solution when it has cooled down to the ambient temperature.

\section{Results and Discussion}

\subsection{Efficacy of mould release agent}

Three concrete industrial mould release agents and seven wax-based types were selected and tried using Mix $1 \mathrm{C}$ (see Table 3). The $100 \mathrm{~mm}^{3}$ samples were steam-cured at 40 to $100{ }^{\circ} \mathrm{C}$ for $24 \mathrm{~h}$ before demoulding. The demoulding process and the surface state of the GC are compared with those of PC concrete and presented in Table 9. 


\begin{tabular}{|c|c|c|c|}
\hline Name & Demoulding process & $\begin{array}{l}\text { Surface state of GC } \\
\text { specimen }\end{array}$ & $\begin{array}{l}\text { Compared to PC } \\
\text { concrete* }^{*}\end{array}$ \\
\hline $\begin{array}{l}\text { Kingfisher's } \\
\text { Mould-Release } \\
\text { Oil }\end{array}$ & $\begin{array}{l}\text { - At } 20 \text { and } 75^{\circ} \mathrm{C} \text { : very hard to clean with more than } 30 \\
\text { minutes and much effort for each mould; GC adhered to } \\
\text { the mould and broken apart at corners or edges. }\end{array}$ & $\begin{array}{l}\text { - Broken concrete and } \\
\text { rough finished surfaces } \\
\text { with aggregates partially } \\
\text { exposed. }\end{array}$ & $\begin{array}{l}\text { Extremely difficult } \\
\text { (impracticable) }\end{array}$ \\
\hline Sika Release & $\begin{array}{l}\text { - At } 20^{\circ} \mathrm{C} \text { : easier to clean compare with Kingfisher's, with } \\
\text { about } 15 \text { minutes for each mould. } \\
\text { - At } 75^{\circ} \mathrm{C} \text { : more than } 15 \text { minutes for each mould and much } \\
\text { effort was needed. }\end{array}$ & $\begin{array}{l}\text { - Rough finished surfaces } \\
\text { but no aggregates } \\
\text { exposed. }\end{array}$ & $\begin{array}{l}\text { Very difficult } \\
\text { (extreme effort) }\end{array}$ \\
\hline Sika Separol W & $\begin{array}{l}\text { - At } 75^{\circ} \mathrm{C} \text { : harder to clean than Sika Release with more } \\
\text { than } 15 \text { minutes compared with. }\end{array}$ & $\begin{array}{l}\text { - Rough finished surfaces } \\
\text { but no aggregates } \\
\text { exposed }\end{array}$ & $\begin{array}{l}\text { Very difficult } \\
\text { (extreme effort) }\end{array}$ \\
\hline $\begin{array}{l}\text { Cherry Blossom } \\
\text { Wax \& Shine }\end{array}$ & $\begin{array}{l}\text { - At } 75^{\circ} \mathrm{C} \text { : less effort to clean each mould compared with } \\
\text { Sika Separol W with about } 15 \text { minutes. }\end{array}$ & $\begin{array}{l}\text { - Rough finished surfaces } \\
\text { but no aggregates } \\
\text { exposed }\end{array}$ & Difficult \\
\hline $\begin{array}{l}\text { NikWax Leather } \\
\text { Cleaner }\end{array}$ & $\begin{array}{l}\text { - At } 75^{\circ} \mathrm{C} \text { : easier to clean with much less effort than Sika } \\
\text { Separol W with about } 12 \text { min for each mould. }\end{array}$ & - Normal finished surfaces & Not difficult \\
\hline Neatsfoot Oil & $\begin{array}{l}\text { - At } 75^{\circ} \mathrm{C} \text { : a little bit easier than NikWax Leather Cleaner } \\
\text { - At } 20^{\circ} \mathrm{C} \text { : much harder to clean with } 20 \text { minutes for each } \\
\text { mould because GC adhered to the mould and was broken } \\
\text { at corners. }\end{array}$ & - Normal finished surfaces & Not difficult \\
\hline Woly Shoe Wax & $\begin{array}{l}\text { - At } 20 \text { and } 75^{\circ} \mathrm{C} \text { : easier than NikWax Leather Cleaner and } \\
\text { less effort clean with about } 10 \text { minutes for each mould. }\end{array}$ & - Normal finished surfaces & Quite easy \\
\hline Vaseline & $\begin{array}{l}\text { - At } 75^{\circ} \mathrm{C} \text { : similar to NikWax Leather Cleaner } \\
\text { - At } 20^{\circ} \mathrm{C} \text { : in between Neatsfoot Oil and Woly Shoe Wax }\end{array}$ & - Normal finished surfaces & Not difficult \\
\hline Z30 Fluid & $\begin{array}{l}\text { - At below } 50^{\circ} \mathrm{C} \text { : easy to clean with less than } 10 \text { minutes } \\
\text { for each mould but still more effort than PC concrete. } \\
\text { - From } 50 \text { to } 75^{\circ} \mathrm{C} \text { : little paste adhered to the mould and } \\
\text { needs more effort to clean with about } 12 \text { minutes for each } \\
\text { mould. } \\
\text { - From } 75 \text { up to } 100^{\circ} \mathrm{C} \text { : GC adhered to the mould quite } \\
\text { hard; needed a hammer and scraper to split the mould out } \\
\text { of each other with hard strikes although } 3 \text { layers of } Z 30 \text { has } \\
\text { been coated before casting using heat gun to dry out. }\end{array}$ & $\begin{array}{l}\text { - Normal finished surfaces } \\
\text { at } 75^{\circ} \mathrm{C} \text { and lower } \\
\text { - Rough finished surfaces } \\
\text { with aggregates partially } \\
\text { exposed at above } 75^{\circ} \mathrm{C}\end{array}$ & Quite easy \\
\hline Waxoyl & - Similar to Z30 Fluid & - Similar to Z30 Fluid & Quite easy \\
\hline $\begin{array}{l}\text { A combination of } \\
\text { Z30 Fluid and } \\
\text { Waxoyl }\end{array}$ & $\begin{array}{l}\text { - Much easier to clean the mould at all temperature with } \\
\text { less than } 10 \text { minutes for each mould and a little bit more } \\
\text { effort than PC concrete. }\end{array}$ & $\begin{array}{l}\text { - Very good finished } \\
\text { surface as PC concrete }\end{array}$ & $\begin{array}{l}\text { Easy } \\
\text { (Simple and } \\
\text { appropriate for } \\
\text { GC) }\end{array}$ \\
\hline
\end{tabular}

301 During the trial with the two commonly used mould release agents Kingfisher and Sika Release (Table 
former caused the concrete to break and leave a rough finished surface with exposed aggregate. An extreme and impracticable effort using a hammer and chisel was also required to clean each steel mould due to the strongly adhered concrete (Table 9). The latter, Sika Release, was slightly better and did not result in broken concrete, but still left rough concrete surfaces with a very great effort required to clean the moulds. The trial also revealed that the elevated curing temperature at $75^{\circ} \mathrm{C}$ caused the concrete to adhere more strongly to the steel mould compared with an ambient curing temperature of $20{ }^{\circ} \mathrm{C}$. This indicates that the presence of alkali in the fresh concrete at high temperature might quickly damage the thin coating layer.

Other attempts were conducted, taking into account the effect of the elevated curing temperature and recommendations of using wax-based agents ( Table 3), including Sika Separol W - a mould release agent suitable for concrete with heated formwork up to $+70^{\circ} \mathrm{C}$; leather treatment waxes, sprayapplied in layers (NikWax Leather, Cherry blossom Wax \& Shine, Neatsfoot Oil, Woly Shoe Wax, and Vaseline); and corrosion protection waxes (Z30 Fluid, a heavy duty waxy film which manufacturer claims works across a temperature range from -20 to $100{ }^{\circ} \mathrm{C}$, and Waxoyl, which creates a waxy waterproof film). Sika Separol was no better than Kingfisher or Sika Release. The leather treatment waxes exhibited a significant improvement in providing a smooth finished surface without exposing the aggregate. However, a significant effort was still required to clean the mould (more than 10 minutes per mould). The most effective leather treatment wax was the Woly Shoe Wax, although a minimum of 3 layers is recommended, with which the effects of bothZ30 Fluid and Waxoyl were comparable.

Finally, instead of applying two or three layers of each agent, a combination of one layer of Z30 Fluid and then another layer of Waxoyl was investigated, with a $12 \mathrm{~h}$ gap for each layer to dry naturally. An excellent smooth finished surface was observed on demoulding, and a minimal effort to clean the mould was required, similar as for typical PC concretes. Although the underling chemical or physical reasoning for this enhanced performance is beyond the scope of this study, the authors highly 
recommend these materials and this process for use with casting GCs. The $12 \mathrm{~h}$ intervals for a natural drying can be reduced by an accelerated drying process.

\subsection{Ease of placement and compaction of fresh GC}

Placement (workability) of fresh GC is more difficult than PC concrete of equivalent slump $[27,80]$ due to the high viscosity of the alkaline activators, owing mainly to the sodium silicate solution. The same conclusion was illustrated in this work as the fresh GC was highly cohesive, and became relatively stiff, especially when the w/s ratio was lower than 0.24 . Mix $1 \mathrm{C}$ (Table 2 ) was compared with a PC concrete mix with the same aggregate content and a water-to-cement ratio of 0.6 . They both resulted in the same slump of $30 \mathrm{~mm}$, but the PC concrete was much easier to place than the stiffer and more cohesive GC. This was also observed during the compaction process. If the PC concrete needed about 30 seconds on the vibration table at an amplitude of $4 / 10$ for full compaction without segregation, the equivalent GC Mix $1 \mathrm{C}$ required more than 30 minutes vibration at an increased amplitude of 6/10. Amplitude here is a relative value, and relates to the vibrations/movements of the vibrating table over time (e.g. per second), rather than actual distance moved. In addition, entrapped air in PC concretes, which contributes to the total voids that negatively affect the compressive strength, can be minimized with an optimum water content for a given compaction method [81]. However, due to high viscosity of activators containing a highly soluble silicate [27], the removal of air voids entrapped within the GC during the casting process requires greater energy inputted into the compaction process. i.e. a greater amplitude of vibration for a longer duration, in particular for low slump mixes [58]. For example, Mix 2A in Table 2 with the $w / s$ ratio of 0.20 , bubbles kept coming up to the cast surface after vibrating for more than 20 minutes at an amplitude of $6 / 10$ (although the number of bubbles reduced with time). This mix did not experience any sign of segregation after more than 30 minutes of compaction. When the w/s ratio increased to 0.3 (Mix 2D) and the amplitude reduced to 4/10, bubbles still appeared after segregation had occurred. This indicates that, unlike PC concrete, compaction by means of a vibration table might not effectively remove all the air-entrapped voids before segregation begins, meaning that compaction is 
inconsistent even for the same mix design, which could encourage misjudgements in the comparisons of the performance of hardened GCs, e.g. the compressive strength and/or porosity.

\subsection{Influence of investigated factors on slump and compressive strength development of GC}

When the GC was cured at $75^{\circ} \mathrm{C}$ and above for at least 24 hours, the 7-day compressive strength was used for analysis instead of 28 days. This is based on the comparisons presented in Table 10, in which more than $93 \%$ of the 28 -day compressive strengths were achieved at 7 days, regardless of FA type, heat curing method, or GGBS inclusion (or not). A similar observation of FA-based GC was also reported [28]. The 28-day strengths were reported only when the water absorption values were measured, or when the strength development over time from 7 to 28 days was discussed, or when the GCs were initially cured at ambient temperatures $\left(10\right.$ or $\left.20^{\circ} \mathrm{C}\right)$. It is worth noting that although the designed density of the $\mathrm{GC}$ was $2400 \mathrm{~kg} / \mathrm{m}^{3}$, the actual measured densities were in the lower range of 2250 to $2410 \mathrm{~kg} / \mathrm{m}^{3}$. These lower values might be due to the air-dry curing period right after demoulding.

Table 10: Ratios of 7- and 28-day compressive strength

Mix Slump Curing Age Density Compressive strength (MPa) $\quad$ 7/28-day

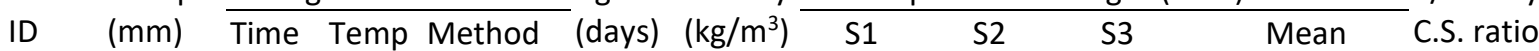

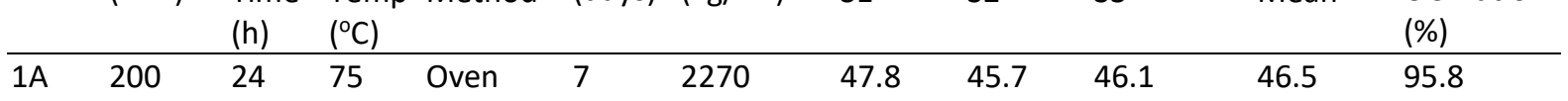

\begin{tabular}{|c|c|c|c|c|c|c|c|c|c|c|}
\hline & & & & 28 & 2250 & 47.7 & 49.9 & 48.1 & 48.6 & \\
\hline $1 \mathrm{~B}$ & 24 & 75 & Steam & 7 & 2260 & 44.7 & 46.0 & 45.3 & 45.3 & 93.2 \\
\hline & & & & 28 & 2230 & 49.0 & 48.4 & 48.5 & 48.6 & \\
\hline \multirow[t]{2}{*}{$1 C$} & 24 & 75 & Steam & 7 & 2330 & 49.1 & 49.5 & 47.4 & 48.7 & 99.2 \\
\hline & & & & 28 & 2310 & 50.9 & 49.1 & 47.2 & 49.1 & \\
\hline \multirow[t]{2}{*}{$2 A^{*}$} & 24 & 75 & Steam & 7 & 2310 & 37.5 & 38.7 & 38.2 & 38.2 & 96.4 \\
\hline & & & & 28 & 2300 & 38.8 & 40.2 & 39.7 & 39.6 & \\
\hline \multirow[t]{2}{*}{$2 C^{*}$} & 24 & 75 & Steam & 7 & 2410 & 104.5 & 104.5 & 105.0 & 104.6 & 96.9 \\
\hline & & & & 28 & 2390 & 108.3 & 107.6 & 108.2 & 108.0 & \\
\hline $4 \mathrm{E}$ & 24 & 75 & Steam & 7 & 2350 & 69.5 & 68.0 & 69.2 & 68.9 & 97.2 \\
\hline & & & & 28 & 2330 & 69.9 & 71.7 & 71.1 & 70.9 & \\
\hline
\end{tabular}

\subsubsection{Oven- and steam-cured methods}

Mixes $1 \mathrm{~A}, 1 \mathrm{~B}$ and $1 \mathrm{C}$ were initially cured by both oven and steam methods at $75^{\circ} \mathrm{C}$ for $24 \mathrm{~h}$. The slump, 
mix design based on the recommendations from $[26,27]$, and Mix $1 \mathrm{~B}$ was designed to have a reduction of $\mathrm{Agg} / \mathrm{GC}$ ratio from 0.77 (for Mix $1 \mathrm{C}$ ) to 0.70 following suggestion by [28]. Mix $1 \mathrm{~A}$ then had a reduction in w/s ratio from 0.22 to 0.20 compared to Mix $1 \mathrm{~B}$, the $\mathrm{w} / \mathrm{s}$ ratio thus being similar to the mixes investigated by [26].

Compared with the oven, the steam curing resulted in equivalent or higher compressive strengths of up to $15 \%$ at 7 days, and $20 \%$ at 28 days for Mix $1 \mathrm{~A}$, as discussed below. This large difference in compressive strengths between the two curing methods compared to those of Mixes $1 \mathrm{~B}$ and $1 \mathrm{C}$ was the reason for only measuring the water absorption at 28 days for Mix $1 \mathrm{~A}$. The results however, showed similar values: $4.6 \%$ by oven and $4.5 \%$ by steam.

Despite having the same w/s of 0.22 , the significant increase in slump from $30 \mathrm{~mm}$ of Mix $1 \mathrm{C}$ to 220 $\mathrm{mm}$ of Mix 1B can be explained by the increase of the paste content by $7 \%$, which not only directly reduced the overall viscosity of the fresh GC but also increased the absolute water content by $32 \%$. In addition, the difference in compressive strength of the steam and oven methods increased from approximately 0 to $12 \%$.

Table 11: Oven- and steam-cured methods of the FA-based GCS

\begin{tabular}{|c|c|c|c|c|c|c|c|c|c|}
\hline \multirow[t]{2}{*}{ Mix ID } & \multirow{2}{*}{$\begin{array}{l}\text { Slump } \\
\text { (mm) }\end{array}$} & \multirow{2}{*}{$\begin{array}{l}\text { Curing } \\
\text { method }\end{array}$} & \multirow{2}{*}{$\begin{array}{l}\text { Age } \\
\text { (days) }\end{array}$} & \multirow{2}{*}{$\begin{array}{l}\text { Density } \\
\left(\mathrm{kg} / \mathrm{m}^{3}\right)\end{array}$} & \multicolumn{4}{|c|}{ Compressive strength ( $\mathrm{MPa})$} & \multirow{2}{*}{$\begin{array}{l}\text { Water } \\
\text { absorption (\%) }\end{array}$} \\
\hline & & & & & S1 & S2 & S3 & Mean & \\
\hline \multirow[t]{4}{*}{$1 \mathrm{~A}$} & 200 & Oven & 7 & 2270 & 47.8 & 45.7 & 46.1 & 46.5 & - \\
\hline & & & 28 & 2250 & 47.7 & 49.9 & 48.1 & 48.6 & 4.6 \\
\hline & & Steam & 7 & 2310 & 55.6 & 52.3 & 52.2 & 53.4 & - \\
\hline & & & 28 & 2310 & 59.2 & 57.4 & 58.6 & 58.4 & 4.4 \\
\hline \multirow[t]{2}{*}{$1 \mathrm{~B}$} & 220 & Oven & 7 & 2260 & 39.6 & 41.6 & 40.7 & 40.6 & - \\
\hline & & Steam & 7 & 2260 & 44.7 & 46.0 & 45.3 & 45.3 & - \\
\hline \multirow[t]{2}{*}{$1 C$} & 30 & Oven & 7 & 2330 & 48.7 & 49.3 & 48.5 & 48.8 & - \\
\hline & & Steam & 7 & 2320 & 49.1 & 49.5 & 47.4 & 48.7 & - \\
\hline
\end{tabular}
Notes: S1-S3 - tested sample 1 to 3.

However, the advantage of the steam over the oven curing on the compressive strengths (as shown in Table 11) contrasts with the observations of Hardjito and Rangan [26], in which the compressive strength of samples with a similar mix proportion cured in an oven were approximately $15 \%$ higher than that cured by steam. This discrepancy was possibly because at a very low water content of 20 to $22 \%$ (of the total solids) with less than $5 \%$ chemically bound in the gel structure of an N-A-S-H system 
[82], it is more crucial to maintain a sufficient amount of water available within the concrete as a medium for the dissolution stage of aluminosilicate particles and transferring ions, and oligomers synthesised, in which the steam curing provided some advantage. It is therefore unlikely to hinder the polycondensation stage occurring at higher $\mathrm{w} / \mathrm{s}$ ratios [83]. Another factor might also be due to the difference between the initial curing temperatures of $60{ }^{\circ} \mathrm{C}$ by [26] and $75{ }^{\circ} \mathrm{C}$ in this research, according to which the rate of strength development could increases by up to 10 times [84].

Figure 3 illustrates the influence of the FA particle size (represented as type $\mathrm{N}$ (coarser) and type $\mathrm{S}$ (finer) and conforming to BS EN 450-1 [48]), on the 7- and 28-day compressive strengths of Mixes 2A, $2 \mathrm{~B}$ and $2 \mathrm{C}$. It is worth noting that Mixes $2 \mathrm{~B}$ and $2 \mathrm{C}$ were identical, except for being initially cured at 20 and $75{ }^{\circ} \mathrm{C}$, which were designed to have $50 \%$ replacement of GGBS with FA compared to Mix $2 \mathrm{~A}$. In addition, they have a higher w/s ratio of 0.24 to achieve a similar workability. These mixes were therefore selected because they were at the boundary of the mix range from FA-based GC to 50/50 GGBS/FA GCs.

The compressive strength of both FA types increased with age up to 28 days depending significantly on the curing temperature and GGBS content. The compressive strengths of the FA-based GC using type $\mathrm{S}$ were $20 \%$ higher than those using type $\mathrm{N}$ at the same age (Figure 3a), consistent with the findings of others [35-37], which showed that finer particles of FA improved the compressive strength. This fineness effect however, was negligible, regardless of the curing temperature of 20 or $75^{\circ} \mathrm{C}$ when $50 \%$ of FA was replaced by GGBS (Figure $3 \mathrm{~b}$ and c); the heat curing at $75{ }^{\circ} \mathrm{C}$ provided a much higher early age strength at 7 days than those cured at an ambient temperature of $20^{\circ} \mathrm{C}$, similar to the observations in Table 10. An inverse trend was observed for the slump, increasing from 30 to $50 \mathrm{~mm}$ for FA-based GC when the fineness decreased, i.e. from type $\mathrm{S}$ to type $\mathrm{N}$; whereas the slump stayed at 15 to $20 \mathrm{~mm}$ with $50 \%$ GGBS, regardless of the FA particle size. 


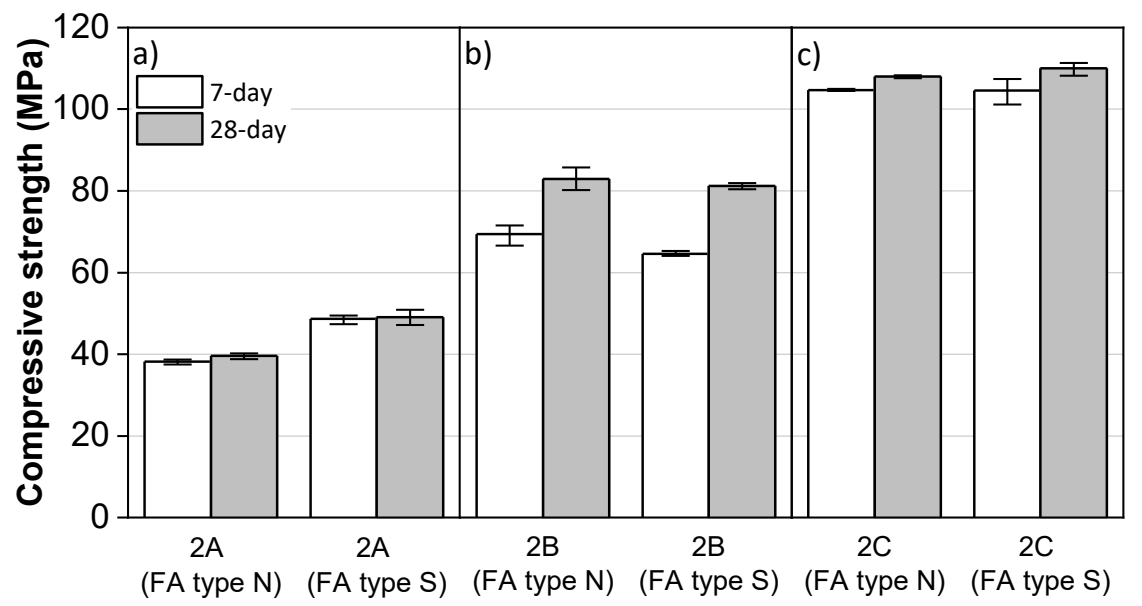

Mix design

Figure 3: Effect of FA type $N$ and $S$ on the compressive strength of GCs containing a) $100 \%$ FA cured at $75^{\circ} \mathrm{C}$ for $24 \mathrm{~h}$; b) $50 / 50 \mathrm{GGBS} / \mathrm{FA}$ cured at $20^{\circ} \mathrm{C}$; and c) $50 / 50 \mathrm{GGBS} / \mathrm{FA}$ cured at $75^{\circ} \mathrm{C}$

for $24 h$.

As observed and discussed in Section 3.2, the workability of GC is considerably lower than PC concrete

with the same $\mathrm{w} / \mathrm{s}$ ratio due to the high viscosity of soluble silicate in the activator compared with water. In addition, to achieve a compressive strength of $35 \mathrm{MPa}$ and above, the w/s ratio of GC might need to be kept as low as 0.22 [26], leading to a significant decrease in the workability. An appropriate high-range water reducing admixture - superplasticizer (SP) - is therefore essential to overcome this issue without increasing the amount of water in the mix design, which would increase the porosity of the binder and hence reduces the mechanical strength. However, because commercially available SPs are currently designed for PC and their variants with additions of mineral admixtures such as FA, GGBS and silica fume, they can have unexpected effects on GC [85]. Apart from the physical properties and chemical composition of FA and GGBS, in which particles' surface-absorbent capability is different from that of $\mathrm{PC}$, the high alkaline environment (i.e. $\mathrm{pH}>13$ ) induced by the activators prompts a chemically unstable state for most types of SP, except for the naphthalene-based group [38]. Comprehensive reviews of additives for alkali-activated GGBS [86] and geopolymer [87] was reported by Rashad; he concluded that naphthalene-based SPs improved both workability and compressive 
strength of the alkali-activated GGBS depending on activator type and concentration, whereas Sika

Viscocrete-3430, a modified polycarboxylate, was recommended for FA-based geopolymer.

Table 12 summarises from literature the effects of five typical commercial SPs, including naphthalenebased, modified polycarboxylate, lignosulfonate, vinyl copolymer, and melamine, on the workability and compressive strength of both GGBS- and FA-activated GCs. The 'positive' effect of the SP on the workability or compressive strength was considered when the former increased effectively, or the latter showed no significant degradation. 'Positive' marks ('+') for both properties indicate an appropriate SP. In other words, the recommended SP has to improve the workability without any negative impact on the compressive strength. According to Table 12, it seems that naphthalene-based

SPs are better suited for both alkali-activated systems, whilst the latest generation of modified polycarboxylate SPs exhibited a 'positive' effect for only FA-based geopolymer.

Table 12: Effects of typical superplasticizers on alkali-activated GGBS and geopolymer

\begin{tabular}{|c|c|c|c|c|c|}
\hline \multirow[t]{2}{*}{ Concrete type } & \multirow{2}{*}{$\begin{array}{l}\text { Superplasticizer } \\
\text { type }\end{array}$} & \multirow{2}{*}{$\begin{array}{l}\text { Workability } \\
++"\end{array}$} & \multicolumn{3}{|c|}{ Compressive strength } \\
\hline & & & "_" & "+" & "_" \\
\hline \multirow{5}{*}{$\begin{array}{l}\text { Alkali- } \\
\text { activated } \\
\text { GGBS }\end{array}$} & Lignosulfonate & [39] & [40]; [41] & & [40]; [41]; [39] \\
\hline & Naphthalene & [39]; [38]; [42] & {$[40]$} & [38] & {$[40] ;[39]$} \\
\hline & Vinyl copolymer & & {$[43] ;[38] ;[42]$} & [38] & [43] \\
\hline & Polycarboxylate & {$[44]$} & {$[43] ;[38] ;[42]$} & [43]; [38] & \\
\hline & Melamine & & {$[38] ;[42]$} & [38] & \\
\hline \multirow[t]{5}{*}{ FA-based } & Lignosulfonate & & {$[45]$} & & \\
\hline & Naphthalene & [26]; [46] & {$[88]$} & [26]; [46] & [88] \\
\hline & Vinyl copolymer & & {$[43]$} & [43] & \\
\hline & Polycarboxylate & [45]; [46] & [43]; [88] & [43] & {$[88] ;[46]$} \\
\hline & Melamine & & {$[45]$} & & \\
\hline Notes: Workability & "+": increase & & mpressive strength & ecre & \\
\hline
\end{tabular}

In addition, Jang et al. [76] recently studied the fresh and hardened properties of blended GGBS/FA geopolymer pastes incorporating naphthalene-based and polycarboxylate-based SPs. They investigated GGBS/(FA+GGBS) ratios of $0,0.3,0.5,0.7$ and 1 , with SP dosages of $0,1,2,3,4 \%$, cured at room temperature. They found that an increase in GGBS content led to a decrease in the workability for both SP types, when $4 \%$ was added. It was also observed that at the GGBS/(FA+GGBS) of 0.5 , and 
based SPs. However, a degradation in compressive strength was also observed when more than $1 \%$ polycarboxylate-based was added.

Based on the above reviews, four SPs from a variety of manufacturers were selected for investigation

in Mix 3: two naphthalenes (Conplast Sp430 and Daracem 215) and two polycarboxylates (Viscocrete

10 and Glenium 51). The mix proportions are shown in Table 2 and the measured compressive strengths, slumps and water absorption are presented in Table 13. Compared to the control mix without SP, the slumps of the mixes increased with all SPs by 60 to $100 \mathrm{~mm}$ from $110 \mathrm{~mm}$, whilst their compressive strengths provided a slight variation within $5 \mathrm{MPa}$. The polycarboxylate group showed some increases in both workability and early compressive strength (compared to the naphthalene), which confirmed the recommendations by Rashad [87] discussed in section 3.3.3. However, regards the GC using Vicoscrete 10, although it had the highest slump, the 28-day compressive strength was

467 about $10 \%$ less than that of the same polycarboxylate type - Glenium 51 . The Glenium 51 therefore, with the highest compressive strength (with a small variance), an average slump and the lowest porosity (Table 13), is recommended.

Table 13: Effect of naphthalene and polycarboxylate SPS on GC.

\begin{tabular}{|c|c|c|c|c|c|c|c|c|c|}
\hline \multirow{2}{*}{$\begin{array}{l}\text { Mix } \\
\text { ID }\end{array}$} & \multirow[t]{2}{*}{ SP type } & \multirow{2}{*}{$\begin{array}{l}\text { Slump } \\
(\mathrm{mm})\end{array}$} & \multirow{2}{*}{$\begin{array}{l}\text { Age } \\
\text { (days) }\end{array}$} & \multirow{2}{*}{$\begin{array}{l}\text { Hardened } \\
\text { Density } \\
\left(\mathrm{kg} / \mathrm{m}^{3}\right)\end{array}$} & \multicolumn{4}{|c|}{ Compressive strength (MPa) } & \multirow{2}{*}{$\begin{array}{l}\text { Water } \\
\text { absorption } \\
(\%)\end{array}$} \\
\hline & & & & & $\mathrm{S1}$ & S2 & S3 & Mean & \\
\hline \multirow[t]{10}{*}{3} & No SP & 110 & 7 & 2330 & 34.6 & 33.9 & 34.3 & 34.2 & - \\
\hline & & & 28 & 2300 & 35.2 & 34.5 & 35.2 & 35.0 & 4.5 \\
\hline & Conplast Sp430 (Fosroc) & 170 & 7 & 2310 & 32.5 & 33.7 & 32.6 & 32.9 & - \\
\hline & & & 28 & 2290 & 34.0 & 33.2 & 33.7 & 33.7 & 4.4 \\
\hline & Daracem 215 (Grace) & 170 & 7 & 2300 & 30.8 & 29.1 & 30.2 & 30.0 & - \\
\hline & & & 28 & 2300 & 31.2 & 31.2 & 31.2 & 31.2 & 5.5 \\
\hline & Viscocrete 10 (Sika) & 210 & 7 & 2340 & 33.2 & 35.0 & 34.5 & 34.2 & - \\
\hline & & & 28 & 2270 & 36.0 & 29.7 & 33.1 & 32.9 & 4.7 \\
\hline & Glenium 51 (BASF) & 180 & 7 & 2330 & 36.4 & 36.1 & 36.3 & 36.3 & - \\
\hline & & & 28 & 2290 & 36.2 & 36.5 & 36.4 & 36.4 & 4.3 \\
\hline
\end{tabular}

\subsubsection{Water-to-solid (w/s) ratio}

473 Figure 4 illustrates the relationship between the $\mathrm{w} / \mathrm{s}$ ratio and the compressive strength of the FAbased GCs with Alk/FA ratios of 0.3 and 0.4 . Increasing the $\mathrm{w} / \mathrm{s}$ ratio resulted in a decrease in the 
compressive strength and an increase in slump, similar to the PC concrete, and consistent with others

$476[26,28,74]$. It is also clear that increasing the Alk/FA ratio from 0.3 to 0.4 improved the compressive strength of the FA-based GCs by 1.5 to 2 times and became more linear with the $\mathrm{w} / \mathrm{s}$ ratio from 0.20 to 0.30 , which is in good agreement with [28]. It is worth noting that within such a small range of w/s ratio (from 0.20 to 0.30 ), the difference in slump was significant, from $10 \mathrm{~mm}$ (S1) to $270 \mathrm{~mm}$ (S5a) [81,89]. A virtually identical trend of non-linear relationship (i.e. an S curve) between the slump and increased with a w/s of 0.24 and above. This might be due to the increase of the highly viscous activator content, which consequently reduces the amount of added water (Table 2 ) for the same w/s ratio. Both of the Alk/FA ratios exhibited a sharp increase in slump when the $\mathrm{w} / \mathrm{s}$ ratios raised narrowly from 0.22 to 0.24 . Outside this range however, the slump gradient reduced. This indicates that the slump of FA-based GC is sensitive to a small change of $w / s$ ratio, within certain ranges. In addition, the water absorption of the mix designs containing a lower Alk/FA ratio of 0.3 rose linearly, as expected, with an increase of the water content, i.e. the porosity, similar to PC concrete.

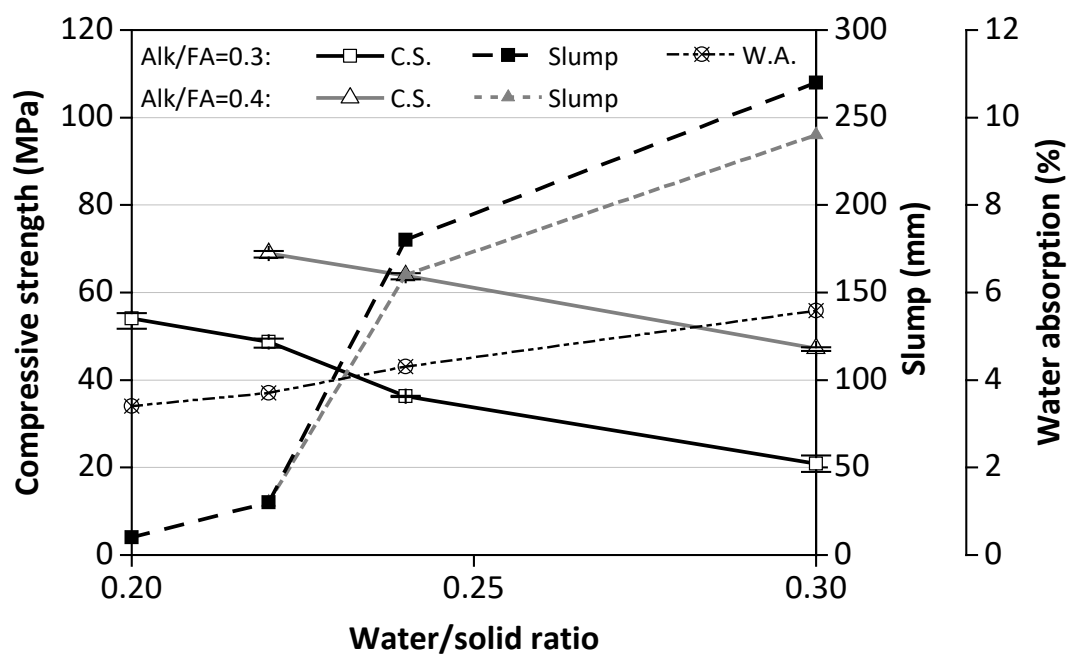




\subsubsection{FA replacement with GGBS}

494

The effect of up to $50 \%$ FA replacement with GGBS on compressive strength and slump of GCs cured at ambient $\left(20^{\circ} \mathrm{C}\right)$ and elevated temperature $\left(75^{\circ} \mathrm{C}\right)$ are shown in Figure 5 . It can be observed that a higher content of GGBS leads to 1) an increase in compressive strength regardless of the curing temperature, consistent with $[23,73,80,90,91]$, and 2 ) a gradual decrease in the workability, similar to observations from $[80,90,92]$. When the blended GCs were cured at $20^{\circ} \mathrm{C}$, the $\mathrm{GGBS} /$ binder ratio in a range from 0 to 0.4 demonstrated a linear relationship with the 28-day compressive strength, corresponding well with Nath and others $[80,90]$ using up to $30 \%$ GGBS replacement. With 40 to $50 \%$ GGBS in the binder, the increase in the compressive strength became minimal (Figure 5). This suggests that at ambient temperatures, the GGBS rather than the FA contributed significantly to the strength development of the GC. When the GGBS content increased from 0 to $40 \%$ or higher, the resulting compressive strength increased from 20 to $80 \mathrm{MPa}$. Of the blended GCs cured at $75^{\circ} \mathrm{C}$ for $24 \mathrm{~h}$, the 7day compressive strength rose rapidly from $35 \mathrm{MPa}$ to more than $85 \mathrm{MPa}$ when the GGBS/binder ratio increased from 0 to $20 \%$, beyond which a slower increase was recorded. A similar trend has also been reported for the binder [93] or mortar [73]. In addition, when more than 20\% GGBS was added (mixes 5D to $5 F$, Table 2), the freshly blended GCs set quickly, which consequently might affect the slump measurement of the FA/GGBS blended GC if the testing process was delayed. These observations are increase in GGBS content [76,80,92]. 


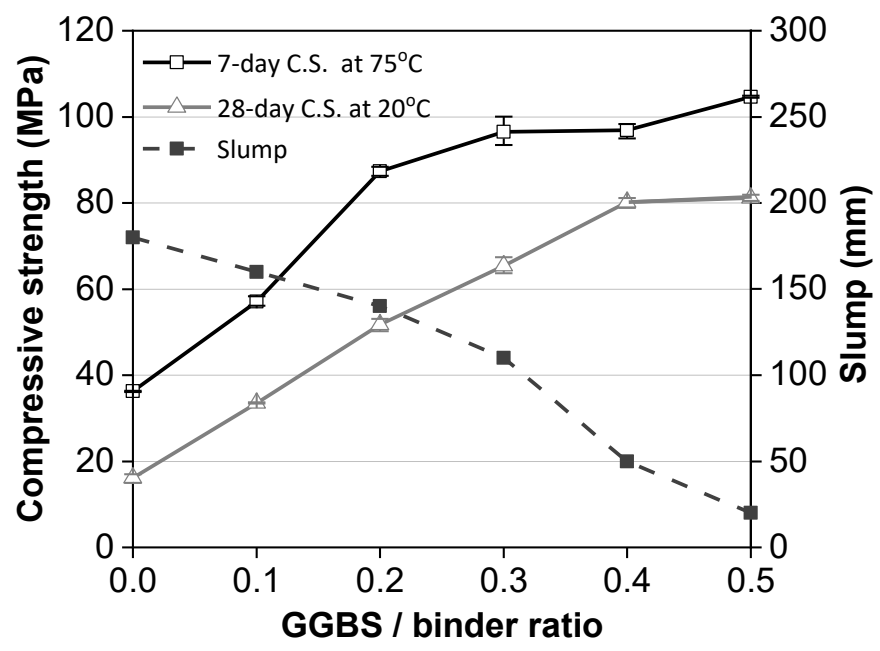

512

Figure 5: 7- and 28-day compressive strengths and slump versus GGBS/binder ratio of blended

GCs cured at 20 and $75^{\circ} \mathrm{C}$, respectively.

\subsubsection{Curing at ambient and low temperatures}

516 Figure 6 presents the compressive strength development of two blended GC mixes with minimal GGBS

517 content to binder of 20 and $30 \%$ and initially cured at ambient $\left(20^{\circ} \mathrm{C}\right)$ or low $\left(10^{\circ} \mathrm{C}\right)$ temperature for

518 up to 28 days. They were selected because the inclusion of GGBS is a possible solution to accelerate

519 (without using heat curing) the hardening process of FA-based geopolymer, which is very slow (in

520 weeks rather than days) at ambient temperature $[26,94,95]$. Three sealed curing methods were used

521 (see section 2.3.2), including:

- Method 1 - samples sealed and cured at 10 or $20^{\circ} \mathrm{C}$ all the time;

- Method 2 - samples sealed and cured at $10{ }^{\circ} \mathrm{C}$ for 7 days, before air-dried at $20^{\circ} \mathrm{C}$; and

- Method 3- samples sealed and cured at $20^{\circ} \mathrm{C}$ for $24 \mathrm{~h}$, before air-dried at $20^{\circ} \mathrm{C}$. 


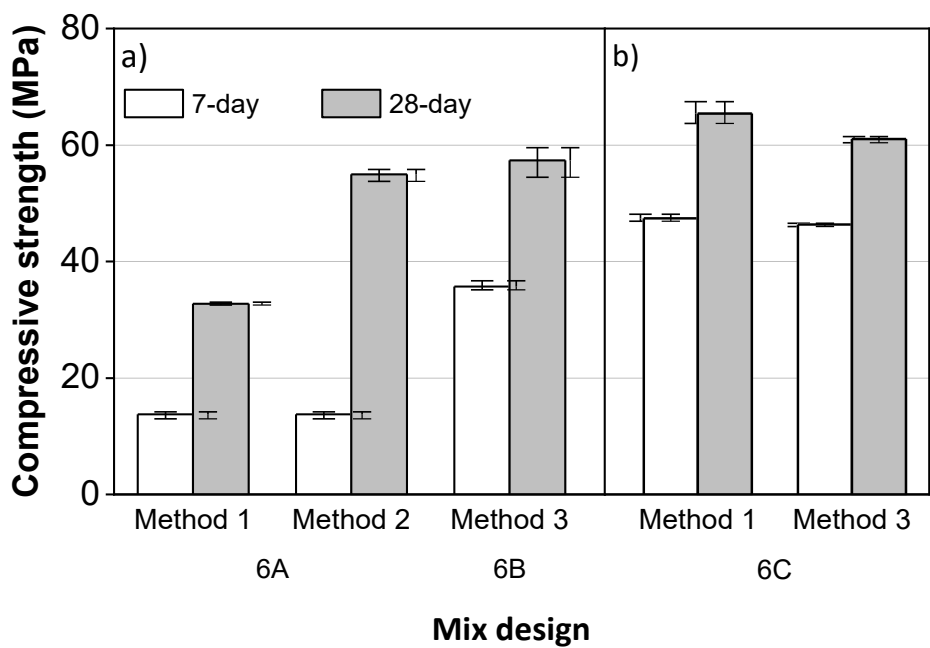

Figure 6: Compressive strength of: a) Mix 6A (curing method 1 and 2), 6B (curing method 3); and b) 6C (curing method 1 and 3).

Figure $6 a$ shows that after being sealed and cured at $10{ }^{\circ} \mathrm{C}$ for 7 days using method 1 or 2 , the compressive strength of the $20 \%$ GGBS mix (Mix 6A or 6B) was very low and achieved only about a third of that cured at $20^{\circ} \mathrm{C}$ by method 3 (Mix 6B). However, by continuing with the air-cured condition at $20{ }^{\circ} \mathrm{C}$ for a further 21 days with method 2, resulted in a comparable 28-day compressive strength to method 3, which was nearly twice as much as with method 1 . It is clear that the prolonged curing at a low temperature of $10^{\circ} \mathrm{C}$ has considerably retarded the polycondensation process of the blended $\mathrm{GC}$, whereas the air-dried period at $20^{\circ} \mathrm{C}$ is more appropriate for accelerating the reaction kinetic that contributes primarily to the strength development. When curing took place at $20{ }^{\circ} \mathrm{C}$ with methods 1 and 3 (Figure 6b), the 7-day compressive strengths were comparable, whilst at 28 days, the strength gained by method 1 was slightly higher. Method 3 however, is more applicable for placing insitu concrete in temperate climates.

\subsubsection{Air dry curing vs water curing of GCs initially cured at 20 and $75^{\circ} \mathrm{C}$} The effect of curing in air or water after the initial $24 \mathrm{~h}$ curing at either 20 or $75^{\circ} \mathrm{C}$ was different for the FA-based (Mix 7A) and FA/GGBS blended (Mixes 7B and 7C) GCs, as shown in Figure 7. It is worth noting that Mixes 7A, 7B and 7C were identical to Mixes 2A, 2B and 2C respectively but at higher water 
contents in order to increase the workability. For the FA-based GC initially cured at $75^{\circ} \mathrm{C}$ for $24 \mathrm{~h}$ and then maintained in water at $20{ }^{\circ} \mathrm{C}$ until tested, the results illustrated a marginal increase in the compressive strength between 28 and 91 days, which was $15 \%$ less than the 28 -day compressive strength of the same mix design maintained in air at $20^{\circ} \mathrm{C}$ and $65 \% \mathrm{RH}$ (Figure 7a). These observations are in agreement with findings based on mortars [47], but the strength development rate of the GC in water in this research was much lower. The presence of water in the pore structure of the N-A-S-(H) gel could explain the differences between the air-cured and water-cured conditions presented here. As described by Duxson et al [96], the polycondensation process releases water, which therefore, as

551 a catalyst or retarder, would be hindered if the pore solution is saturated, or facilitated if it is dried.

552 The 50/50 GGBS/FA GC showed the opposite trend however, in which prolonged curing in water 553 improved the 28 -day compressive strength by more than $20 \%$ compared with the air-dried curing 554 condition, although the mix contained a high w/s ratio, which was equivalent to the strength of Mix $5557 \mathrm{C}$ cured in air after initial curing at $75{ }^{\circ} \mathrm{C}$ for $24 \mathrm{~h}$ (Figure $7 \mathrm{~b}$ ). It seems that with a $50 \%$ GGBS substitution, the C-N-A-S-H gel containing a high bound water content becomes predominant $[22,97]$, which consumes more water for the ongoing gel evolution (and thus strength development) of such a high calcium system. In addition, there were differences between the densities of the GC cured in water and in air, greater for FA-based GC (Mix 7A) of 2360 and $2250 \mathrm{~kg} / \mathrm{m}^{3}$ and less for 50/50 GGBS/FA GC of 2390 and 2350

$561 \mathrm{~kg} / \mathrm{m}^{3}$, respectively. However, the water-saturated densities of GCs are comparable to that of OPC concrete. This again confirmed that the assumption in the mix design calculations was appropriate. 


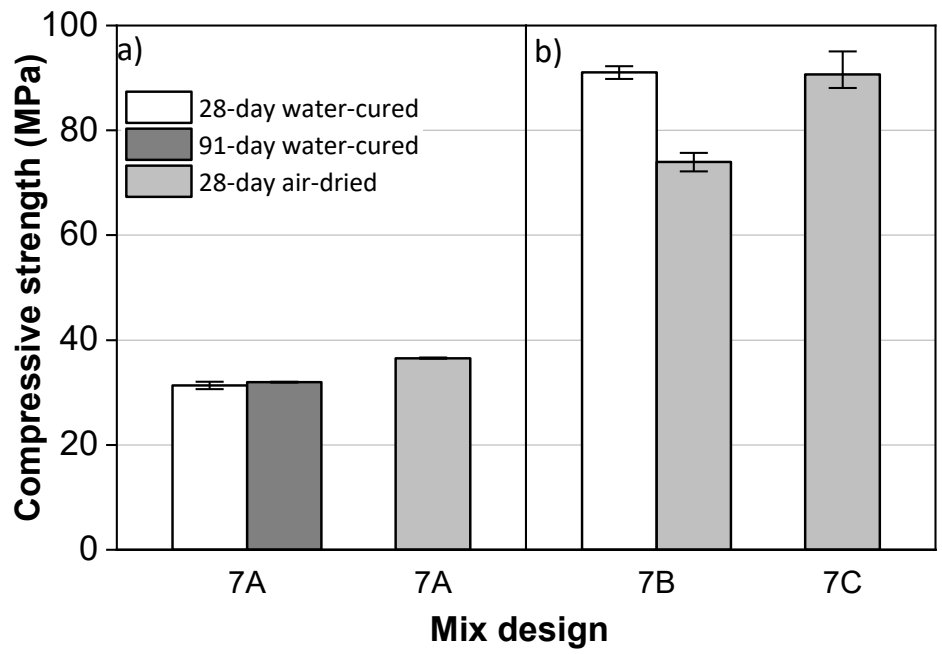

Figure 7: Effect of curing conditions on the compressive strength of GCs with a) 100\% FA and

b) $50 \%$ GGBS.

\section{Conclusions}

567 Experiments were conducted to systematically investigate the following factors influencing the slump and strength development of FA-based GC with a substitution of up to $50 \%$ GGBS: FA particle fineness, FA replacement with GGBS, superplasticiser type, initial curing condition (steam or oven), curing condition (air or water), initial curing temperature $\left(10,20\right.$ and $\left.75^{\circ} \mathrm{C}\right)$, and the water-to-solid ratio. Suitable mould release agents were trialled and identified, and a volume-to-mass conversion method of sodium hydroxide solution at a specific molarity and temperature was developed. The following conclusions can be drawn:

i. A volume-to-mass conversion of sodium hydroxide solution was developed based on the designed molarity and the ambient temperature at which the GC is cast, where the results are within 4\% compared to literature [26]. The converted masses of solid sodium hydroxide for 1 $\mathrm{kg}$ solution or water are presented in Table 6, in which the use of $1 \mathrm{~kg}$ solution is recommended because the evaporated water by heat during the dissolving process can be balanced out when the solution cools down to ambient temperature. 
ii. The mould release agents available for PC concrete are mostly inappropriate for GCs because they caused rough finished surfaces, sometimes with exposed aggregate, as well as requiring extreme effort to clean the steel moulds when de-moulding. A combination of Z30 Fluid and Waxoyl (wax-based agents) is recommended for GC, providing an excellent finished surface with minimal cleaning effort, similar to PC concrete.

iii. The ease of placement of GC is considerably lower than comparable PC of a similar slump. Mechanical vibration removes a significant amount of the air entrapped within the GC due to its high viscosity. However, the effectiveness of this vibration decreases as the $\mathrm{w} / \mathrm{s}$ ratio

vii. An increase of $\mathrm{w} / \mathrm{s}$ ratio, i.e. water content, from 0.2 to 0.3 decreased the compressive strength of the FA-based GC approximately linearly with alkaline-to-binder ratios of 0.3 and 0.4. It increased the water absorption however, of the FA-based GC with an alkaline-to-binder ratio of 0.3 . The slump increased with the increase in the $\mathrm{w} / \mathrm{s}$ ratio regardless of the alkaline to binder ratio; however, a sharp rise in slump occurred in a small range of $\mathrm{w} / \mathrm{s}$ ratios from 0.22 to 0.24 . Outside this range, the effect of additional water quickly becomes marginal. 
viii. Increasing the GGBS content in the GCs significantly increased the compressive strength regardless of curing temperature of 20 or $75{ }^{\circ} \mathrm{C}$, but it slightly decreased the slump of the same $\mathrm{w} / \mathrm{s}$ ratio mixes. At $20^{\circ} \mathrm{C}$, the increase in compressive strength became negligible when the GGBS content was beyond $40 \%$, reaching $80 \mathrm{MPa}$ after 28 days, whereas a similar change occurred when the GC was substituted by $20 \%$ GGBS and cured at $75^{\circ} \mathrm{C}$.

ix. Having retarded considerably the polycondensation process of the $20 \%$ GGBS GC in a prolonged curing process at $10{ }^{\circ} \mathrm{C}$, a moderate 28 -day compressive strength of $33 \mathrm{MPa}$ was achieved.

x. Between the air-dry and water-cured methods, the former improved the compressive strength development of the FA-based GCs whereas the latter enhanced the blended GC with up to $50 \%$ GGBS.

These findings contribute to the understanding of GC systems including the practical knowledge required for the increased industrial application of GCs, enhancing the potential for the increased application of GC in real structures, and consequently helping reduce global $\left(\mathrm{CO}_{2}\right)$ emissions. They also contribute into the later phases of our research programme, reported elsewhere $[24,25]$.

\section{Acknowledgement}

The authors wish to express their thanks to Hanson PIc for providing the GGBS, and also to the School of Architecture, Building and Civil Engineering, Loughborough University for their financial support for the associated PhD programme.

\section{References}

[1] CEMBUREAU, Activity report 2016, Brussels, 2016.

[2] K.L. Scrivener, R.J. Kirkpatrick, Innovation in use and research on cementitious material, Cem. Concr. Res. 38 (2008) 128-136. doi:10.1016/j.cemconres.2007.09.025.

[3] J.G.J. Olivier, M. Muntean, Trends in global CO2 emissions: 2015 report, The Hague, 2015.

[4] A. Hasanbeigi, L. Price, E. Lin, Emerging energy-efficiency and $\mathrm{CO} 2$ emission-reduction 
technologies for cement and concrete production: A technical review, Renew. Sustain. Energy Rev. 16 (2012) 6220-6238. doi:10.1016/j.rser.2012.07.019.

[5] V.M. Malhotra, High-volume fly ash and slag concrete, in: V.S. Ramachandran (Ed.), Concr. Admixtures Handb. Prop. Sci. Technol., 2nd ed., Noyes Publications, Park Ridge, NJ, 1996: pp. 800-838. doi:10.1016/B978-081551373-5.50016-7.

[6] A.M. Rashad, A brief on high-volume Class F fly ash as cement replacement - A guide for Civil Engineer, Int. J. Sustain. Built Environ. 4 (2015) 278-306. doi:10.1016/j.ijsbe.2015.10.002.

[7] M.C.G. Juenger, F. Winnefeld, J.L. Provis, J.H. Ideker, Advances in alternative cementitious binders, Cem. Concr. Res. 41 (2011) 1232-1243. doi:10.1016/j.cemconres.2010.11.012.

[8] M.S. Imbabi, C. Carrigan, S. McKenna, Trends and developments in green cement and concrete technology, Int. J. Sustain. Built Environ. 1 (2012) 194-216. doi:10.1016/j.ijsbe.2013.05.001.

[9] J.L. Provis, J.S.J. van Deventer, Alkali Activated Materials: State-of-the-Art Report, RILEM TC 224-AAM, 2014. doi:10.1007/978-94-007-7672-2.

[10] Y. Yao, Y. Li, X. Liu, H. Sun, S. Jiang, C. Feng, Performance and energy calculation on a green cementitious material composed of coal refuse, Clean Technol. Environ. Policy. 16 (2014) 281290. doi:10.1007/s10098-013-0620-8.

[11] G. Habert, J.B. d'Espinose de Lacaillerie, N. Roussel, An environmental evaluation of geopolymer based concrete production: reviewing current research trends, J. Clean. Prod. 19 (2011) 1229-1238. doi:10.1016/j.jclepro.2011.03.012.

[12] J.L. Provis, S.A. Bernal, Geopolymers and Related Alkali-Activated Materials, Annu. Rev. Mater. Res. 44 (2014) 299-327. doi:10.1146/annurev-matsci-070813-113515.

[13] Z. Li, Z. Ding, Y. Zhang, Development of sustainable cementitious materials, in: Proc. Int. Work. Sustain. Dev. Concr. Technol., 2004: pp. 55-76.

[14] P. Duxson, J.L. Provis, G.C. Lukey, J.S.J. van Deventer, The role of inorganic polymer technology in the development of 'green concrete,' Cem. Concr. Res. 37 (2007) 1590-1597. doi:10.1016/j.cemconres.2007.08.018. 
[15] J.L. Provis, A. Palomo, C. Shi, Advances in understanding alkali-activated materials, Cem. Concr. Res. 78 (2015) 110-125. doi:10.1016/j.cemconres.2015.04.013.

[16] J. Davidovits, Geopolymers: inorganic polymeric new materials, J. Therm. Anal. 37 (1991) 16331656. doi:10.1007/BF01912193.

[17] J. Davidovits, Geopolymer Chemistry and Applications, 4th ed., Institut Géopolymère, SaintQuentin, 2015.

[18] P. Duxson, J.L. Provis, G.C. Lukey, F. Separovic, J.S.J. van Deventer, 29Si NMR study of structural ordering in aluminosilicate geopolymer gels, Langmuir. 21 (2005) 3028-3036. doi:10.1021/la047336x.

[19] A. Fernández-Jiménez, A. Palomo, Composition and microstructure of alkali activated fly ash binder: Effect of the activator, Cem. Concr. Res. 35 (2005) 1984-1992. doi:10.1016/j.cemconres.2005.03.003.

[20] R.J. Myers, S.A. Bernal, R. San Nicolas, J.L. Provis, Generalized structural description of calciumsodium aluminosilicate hydrate gels: The cross-linked substituted tobermorite model, Langmuir. 29 (2013) 5294-5306. doi:10.1021/la4000473.

[21] J. Skibsted, M.D. Andersen, The effect of alkali ions on the incorporation of aluminum in the calcium silicate hydrate (C-S-H) phase resulting from portland cement hydration studied by 29Si MAS NMR, J. Am. Ceram. Soc. 96 (2013) 651-656. doi:10.1111/jace.12024.

[22] I. Ismail, S.A. Bernal, J.L. Provis, R. San Nicolas, S. Hamdan, J.S.J. van Deventer, Modification of phase evolution in alkali-activated blast furnace slag by the incorporation of fly ash, Cem. Concr. Compos. 45 (2014) 125-135. doi:10.1016/j.cemconcomp.2013.09.006.

[23] N. Marjanović, M. Komljenović, Z. Baščarević, V. Nikolić, R. Petrović, Physical-mechanical and microstructural properties of alkali-activated fly ash-blast furnace slag blends, Ceram. Int. 41 (2015) 1421-1435. doi:10.1016/J.CERAMINT.2014.09.075.

[24] T.T. Nguyen, C.I. Goodier, S.A. Austin, Effect of constituent parameters on the workability and compressive strength of geopolymer concrete, Constr. Build. Mater. (2020) (In preparation). 
[25] T.T. Nguyen, C.I. Goodier, S.A. Austin, Influence of GGBS on the corrosion resistance of geopolymer concrete, Cem. Concr. Res. (2020) (In preparation).

[26] D. Hardjito, B.V. Rangan, Development and properties of low-calcium fly ash-based geopolymer concrete, Res. Rep. GC. (2005) 94.

[27] M. Olivia, H. Nikraz, Properties of fly ash geopolymer concrete designed by Taguchi method, Mater. Des. 36 (2012) 191-198. doi:10.1016/j.matdes.2011.10.036.

[28] B. Joseph, G. Mathew, Influence of aggregate content on the behavior of fly ash based geopolymer concrete, Sci. Iran. 19 (2012) 1188-1194. doi:10.1016/j.scient.2012.07.006.

[29] N.K. Lee, H.K. Lee, Setting and mechanical properties of alkali-activated fly ash/slag concrete manufactured at room temperature, Constr. Build. Mater. 47 (2013) 1201-1209. doi:10.1016/j.conbuildmat.2013.05.107.

[30] A. Noushini, A. Castel, The effect of heat-curing on transport properties of low-calcium fly ashbased geopolymer concrete, Constr. Build. Mater. 112 (2016) 464-477. doi:10.1016/j.conbuildmat.2016.02.210.

[31] B.V. Rangan, Low-Calcium, Fly-Ash-Based Geopolymer Concrete, in: E.G. Nawy (Ed.), Concr. Constr. Eng. Handb., CRC Press, London, 2008: pp. 26.1-19.

[32] M.T. Junaid, O. Kayali, A. Khennane, J. Black, A mix design procedure for low calcium alkali activated fly ash-based concretes, Constr. Build. Mater. 79 (2015) 301-310. doi:10.1016/j.conbuildmat.2015.01.048.

[33] P. Pavithra, M. Srinivasula Reddy, P. Dinakar, B. Hanumantha Rao, B.K. Satpathy, A.N. Mohanty, A mix design procedure for geopolymer concrete with fly ash, J. Clean. Prod. 133 (2016) 117125. doi:10.1016/j.jclepro.2016.05.041.

[34] A. Rafeet, R. Vinai, M. Soutsos, W. Sha, Guidelines for mix proportioning of fly ash/GGBS based alkali activated concretes, Constr. Build. Mater. 147 (2017) 130-142. doi:10.1016/j.conbuildmat.2017.04.036.

[35] A. Van Riessen, N. Chen-Tan, Beneficiation of Collie fly ash for synthesis of geopolymer Part 2 - 
Geopolymers, Fuel. 111 (2013) 829-835. doi:10.1016/j.fuel.2013.04.015.

710

711

712

713

714

715

716

717

718

719

720

721

722

723

724

725

726

727

728

729

730

731

732

733

734

[36] E.I. Diaz, E.N. Allouche, S. Eklund, Factors affecting the suitability of fly ash as source material for geopolymers, Fuel. 89 (2010) 992-996. doi:10.1016/j.fuel.2009.09.012.

[37] S. Kumar, R. Kumar, T.C. Alex, A. Bandopadhyay, S.P. Mehrotra, Influence of reactivity of fly ash on geopolymerisation, Adv. Appl. Ceram. 106 (2007) 120-127. doi:10.1179/174367607X159293.

[38] M. Palacios, F. Puertas, Effect of superplasticizer and shrinkage-reducing admixtures on alkaliactivated slag pastes and mortars, Cem. Concr. Res. 35 (2005) 1358-1367. doi:10.1016/j.cemconres.2004.10.014.

[39] T. Bakharev, J.G. Sanjayan, Y.B. Cheng, Effect of admixtures on properties of alkali-activated slag concrete, Cem. Concr. Res. 30 (2000) 1367-1374. doi:10.1016/S0008-8846(00)00349-5.

[40] E. Douglas, J. Brandstetr, A preliminary study on the alkali activation of ground granulated blast-furnace slag, Cem. Concr. Res. 20 (1990) 746-756. doi:10.1016/0008-8846(90)90008-L.

[41] S.-D. Wang, K.L. Scrivener, P.L. Pratt, Factors affecting the strength of alkali-activated slag, Cem. Concr. Res. 24 (1994) 1033-1043. doi:10.1016/0008-8846(94)90026-4.

[42] M. Palacios, P.F.G. Banfill, F. Puertas, Rheology and setting of alkali-activated slag pastes and mortars: Effect if organic admixture, ACI Mater. J. 105 (2008) 140-148.

[43] F. Puertas, J.D. Izquierdo, M.L. Granizo, A. Palomo, A. Fernández-Jiménez, Effect of superplasticisers on the behaviour and properties of alkaline cements, Adv. Cem. Res. 15 (2003) 23-28. doi:10.1680/adcr.2003.15.1.23.

[44] A. Kashani, J.L. Provis, J. Xu, A. Kilcullen, P. Duxson, G.G. Qiao, J.S.J. van Deventer, Effects of Different Polycarboxylate Ether Structures on the Rheology of Alkali-Activated Slag Binders, Spec. Publ. 288 (2012) 279-289. doi:10.14359/51684235.

[45] M. Criado, A. Palomo, A. Fernández-Jiménez, P.F.G. Banfill, Alkali activated fly ash: effect of admixtures on paste rheology, Rheol. Acta. 48 (2009) 447-455. doi:10.1007/s00397-008-03455. 
[46] B. Nematollahi, J. Sanjayan, Effect of different superplasticizers and activator combinations on workability and strength of fly ash based geopolymer, Mater. Des. 57 (2014) 667-672. doi:10.1016/j.matdes.2014.01.064.

[47] A. Fernandez-Jimenez, I. García-Lodeiro, A. Palomo, Durability of alkali-activated fly ash cementitious materials, J. Mater. Sci. 42 (2007) 3055-3065. doi:10.1007/s10853-006-0584-8.

[48] British Standards Institution, BS EN 450-1:2012. Fly ash for concrete Part 1: Definition, specifications and conformity criteria, BSI, London, 2012.

[49] British Standards Institution, BS EN 15167-1:2006. Ground granulated blast furnace slag for use in concrete, mortar and grout. Definitions, specifications and conformity criteria, BSI, London, 2006.

[50] British Standards Institution, BS EN 1097-6:2013. Tests for mechanical and physical properties of aggregates. Determination of particle density and water absorption, BSI, London, 2013.

[51] British Standards Institution, BS EN 933-1:2012. Tests for geometrical properties of aggregates. Determination of particle size distribution. Sieving method, BSI, London, 2012.

[52] British Standards Institution, BS EN 1097-5:2008. Tests for mechanical and physical properties of aggregates. Determination of the water content by drying in a ventilated oven, BSI, 2008.

[53] A.M.M. Al Bakri, H. Kamarudin, M. Bnhussain, I.K. Nizar, A.R. Rafiza, Y. Zarina, The Processing, Characterization, and Properties of Fly Ash Based Geopolymer Concrete, Rev. Adv. Mater. Sci. 30 (2012) 90-97.

[54] A.M. Mustafa Al Bakri, H. Kamarudin, M. Bnhussain, A.R. Rafiza, Y. Zarina, Effect of $\mathrm{Na} 2 \mathrm{SiO} / \mathrm{NaOH}$ ratios and $\mathrm{NaOH}$ molarities on compressive strength of fly-ash-based geopolymer, ACI Mater. J. 109 (2012) 503-508.

[55] M.M.A. Abdullah, H. Kamarudin, M. Bnhussain, I. Khairul Nizar, A.R. Rafiza, Y. Zarina, The Relationship of $\mathrm{NaOH}$ Molarity, $\mathrm{Na} 2 \mathrm{SiO} 3 / \mathrm{NaOH}$ Ratio, Fly Ash/Alkaline Activator Ratio, and Curing Temperature to the Strength of Fly Ash-Based Geopolymer, Adv. Mater. Res. 328-330 (2011) 1475-1482. doi:10.4028/www.scientific.net/AMR.328-330.1475. 
[56] A. Noushini, M. Babaee, A. Castel, Suitability of heat-cured low-calcium fly ash-based geopolymer concrete for precast applications, Mag. Concr. Res. 68 (2016) 163-177. doi:10.1680/macr.15.00065.

[57] P. de Caro, C. Djelal, L. Libessart, I. Dubois, Influence of the nature of the demoulding agent on the properties of the formwork-concrete interface, Mag. Concr. Res. 59 (2007) 141-149. doi:10.1680/macr.2007.59.2.141.

[58] T. Gourley, P. Duxson, S. Setunge, N. Lloyd, M. Dechsler, W. South, Geopolymer concrete recommended practice, Concrete Institute of Australia, Sydney, 2011.

[59] K.K. Sagoe-Crentsil, S. Yan, L. Gesthuizen, Geopolymer product, WO2013044325 A1, 2013.

[60] British Standards Institution, BS EN 12390-1:2012. Testing hardened concrete. Shape, dimensions and other requirements for specimens and moulds, BSI, London, 2012.

[61] Kingfisher Technical Department, Kingfisher mould release oil, (2011). http://www.kingfisheruk.com/item_05m_mould_release_agent.

[62] Sika, Sika release, (2011). https://sikaconcrete.co.uk/wp-content/uploads/2017/10/sikarelease-ebp-pds.pdf.

[63] Rocol, Z30 fluid \& spray, (2011). https://www.rocol.com/products/z30-outdoor-corrosioninhibitor.

[64] Sika, Sika Separol W, (2009). https://gbr.sika.com/en/solutions_products/sikamarkets/concrete-admixtures/02a001/concrete-accessories/concrete-accessoryproducts.html.

[65] Hammerite, Waxoyl, (2013). https://www.hammerite.co.uk/product/waxoyl/.

[66] British Standards Institution, BS EN 12350-2:2009. Testing fresh concrete. Slump-test, BSI, London, 2009.

[67] British Standards Institution, BS EN 12390-7:2009. Testing hardened concrete. Density of hardened concrete, BSI, London, 2009.

[68] British Standards Institution, BS EN 12390-3:2009. Testing hardened concrete. Compressive 
strength of test specimens, BSI, London, 2009.

[69] ASTM International, ASTM C642-13. Standard Test Method for Density, Absorption, and Voids in Hardened Concrete, West Conshohocken, PA, 2013. doi:10.1520/C0642-13.5.

[70] D.W. Law, A.A. Adam, T.K. Molyneaux, I. Patnaikuni, Durability assessment of alkali activated slag (AAS) concrete, Mater. Struct. 45 (2012) 1425-1437. doi:10.1617/s11527-012-9842-1.

[71] R.R. Lloyd, J.L. Provis, J.S.J. van Deventer, Microscopy and microanalysis of inorganic polymer cements. 1: remnant fly ash particles, J. Mater. Sci. 44 (2009) 608-619. doi:10.1007/s10853008-3077-0.

[72] R. Vinai, A. Rafeet, M. Soutsos, W. Sha, The Role of Water Content and Paste Proportion on Physico-mechanical Properties of Alkali Activated Fly Ash-Ggbs Concrete, J. Sustain. Metall. 2 (2015) 51-61. doi:10.1007/s40831-015-0032-6.

[73] M. Soutsos, A.P. Boyle, R. Vinai, A. Hadjierakleous, S.J. Barnett, Factors influencing the compressive strength of fly ash based geopolymers, Constr. Build. Mater. 110 (2016) 355-368. doi:10.1016/j.conbuildmat.2015.11.045.

[74] A.A. Aliabdo, A.E.M. Abd Elmoaty, H.A. Salem, Effect of water addition, plasticizer and alkaline solution constitution on fly ash based geopolymer concrete performance, Constr. Build. Mater. 121 (2016) 694-703. doi:10.1016/j.conbuildmat.2016.06.062.

[75] E.W. Washburn, ed., International critical tables of numerical data, physics, chemistry and technology, Knovel, New York, 1926.

[76] J.G. Jang, N.K. Lee, H.K. Lee, Fresh and hardened properties of alkali-activated fly ash/slag pastes with superplasticizers, Constr. Build. Mater. 50 (2014) 169-176. doi:10.1016/j.conbuildmat.2013.09.048.

[77] A. Palomo, M.W. Grutzeck, M.T. Blanco, Alkali-activated fly ashes: A cement for the future, Cem. Concr. Res. 29 (1999) 1323-1329. doi:10.1016/S0008-8846(98)00243-9.

[78] S.A. Bernal, J.L. Provis, D.G. Brice, A. Kilcullen, P. Duxson, J.S.J. van Deventer, Accelerated carbonation testing of alkali-activated binders significantly underestimates service life: The 
role of pore solution chemistry, Cem. Concr. Res. 42 (2012) 1317-1326. doi:10.1016/j.cemconres.2012.07.002.

[79] D.W. Law, A.A. Adam, T.K. Molyneaux, I. Patnaikuni, A. Wardhono, Long term durability properties of class F fly ash geopolymer concrete, Mater. Struct. (2014) 1-11. doi:10.1617/s11527-014-0268-9.

[80] P. Nath, P.K. Sarker, Effect of GGBFS on setting, workability and early strength properties of fly ash geopolymer concrete cured in ambient condition, Constr. Build. Mater. 66 (2014) 163-171. doi:10.1016/j.conbuildmat.2014.05.080.

[81] A.M. Neville, Properties of concrete, 5th ed., Pearson, Harlow, England, 2011.

[82] C.E. White, J.L. Provis, T. Proffen, J.S.J. van Deventer, The effects of temperature on the local structure of metakaolin-based geopolymer binder: A neutron pair distribution function investigation, J. Am. Ceram. Soc. 93 (2010) 3486-3492. doi:10.1111/j.15512916.2010.03906.x.

[83] Z. Zuhua, Y. Xiao, Z. Huajun, C. Yue, Role of water in the synthesis of calcined kaolin-based geopolymer, Appl. Clay Sci. 43 (2009) 218-223. doi:10.1016/j.clay.2008.09.003.

[84] Á. Palomo, S. Alonso, A. Fernandez-Jiménez, I. Sobrados, J. Sanz, Alkaline Activation of Fly Ashes: NMR Study of the Reaction Products, J. Am. Ceram. Soc. 87 (2004) 1141-1145. doi:10.1111/j.1551-2916.2004.01141.x.

[85] F. Puertas, M. Palacios, J.L. Provis, Admixtures, in: J.L. Provis, J.S.J. van Deventer (Eds.), Alkali Act. Mater. State-of-the-Art Reports, RILEM TC 224-AAM, Springer, Dordrecht, 2014: pp. 145156. doi:10.1007/978-94-007-7672-2_6.

[86] A.M. Rashad, A comprehensive overview about the influence of different additives on the properties of alkali-activated slag - A guide for Civil Engineer, Constr. Build. Mater. 47 (2013) 29-55. doi:10.1016/j.conbuildmat.2013.04.011.

[87] A.M. Rashad, A comprehensive overview about the influence of different admixtures and additives on the properties of alkali-activated fly ash, Mater. Des. 53 (2014) 1005-1025. 
doi:10.1016/j.matdes.2013.07.074.

[88] D.L.Y. Kong, J.G. Sanjayan, Effect of elevated temperatures on geopolymer paste, mortar and concrete, Cem. Concr. Res. 40 (2010) 334-339. doi:10.1016/j.cemconres.2009.10.017.

[89] British Standards Institution, BS EN 206:2013. Concrete. Specification, performance, production and conformity, BSI, London, 2013.

[90] P.S. Deb, P. Nath, P.K. Sarker, The effects of ground granulated blast-furnace slag blending with fly ash and activator content on the workability and strength properties of geopolymer concrete cured at ambient temperature, Mater. Des. 62 (2014) 32-39. doi:10.1016/j.matdes.2014.05.001.

[91] S. Chithiraputhiran, N. Neithalath, Isothermal reaction kinetics and temperature dependence of alkali activation of slag, fly ash and their blends, Constr. Build. Mater. 45 (2013) 233-242. doi:10.1016/j.conbuildmat.2013.03.061.

[92] W.C. Wang, H.Y. Wang, M.H. Lo, The fresh and engineering properties of alkali activated slag as a function of fly ash replacement and alkali concentration, Constr. Build. Mater. 84 (2015) 224-229. doi:10.1016/j.conbuildmat.2014.09.059.

[93] J.I. Escalante García, K. Campos-Venegas, A. Gorokhovsky, A. Fernández, Cementitious composites of pulverised fuel ash and blast furnace slag activated by sodium silicate: effect of Na2O concentration and modulus, Adv. Appl. Ceram. 105 (2006) 201-208. doi:10.1179/174367606X120151.

[94] F. Puertas, S. Martínez-Ramírez, S. Alonso, T. Vázquez, Alkali-activated fly ash/slag cements: Strength behaviour and hydration products, Cem. Concr. Res. 30 (2000) 1625-1632. doi:10.1016/S0008-8846(00)00298-2.

[95] G. Kovalchuk, A. Fernández-Jiménez, A. Palomo, Alkali-activated fly ash: Effect of thermal curing conditions on mechanical and microstructural development - Part II, Fuel. 86 (2007) 315-322. doi:10.1016/j.fuel.2006.07.010.

[96] P. Duxson, A. Fernández-Jiménez, J.L. Provis, G.C. Lukey, A. Palomo, J.S.J. van Deventer, 
Geopolymer technology: the current state of the art, J. Mater. Sci. 42 (2007) 2917-2933. doi:10.1007/s10853-006-0637-z.

867 [97] J.L. Provis, R.J. Myers, C.E. White, V. Rose, J.S.J. van Deventer, X-ray microtomography shows pore structure and tortuosity in alkali-activated binders, Cem. Concr. Res. 42 (2012) 855-864. doi:10.1016/j.cemconres.2012.03.004.

870 